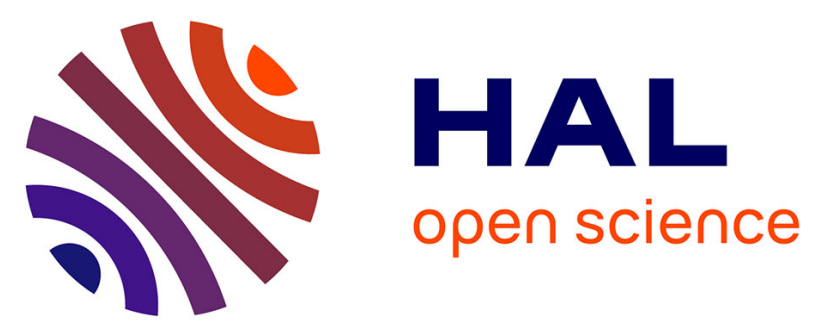

\title{
Polyheteroaryl Oxazole/Pyridine-Based Compounds Selected in Vitro as G-Quadruplex Ligands Inhibit Rock Kinase and Exhibit Antiproliferative Activity
}

Daniela Verga, Chi-Hung N'Guyen, Daniela Verga, Chi-Hung N'Guyen, Malika Dakir, Jean-Luc Coll, Marie-Paule Teulade-Fichou, Annie Molla

\section{To cite this version:}

Daniela Verga, Chi-Hung N'Guyen, Daniela Verga, Chi-Hung N'Guyen, Malika Dakir, et al.. Polyheteroaryl Oxazole/Pyridine-Based Compounds Selected in Vitro as G-Quadruplex Ligands Inhibit Rock Kinase and Exhibit Antiproliferative Activity. Journal of Medicinal Chemistry, 2018, 10.1021/acs.jmedchem.8b01023 . hal-02392101

\section{HAL Id: hal-02392101 \\ https://hal.science/hal-02392101}

Submitted on 3 Dec 2019

HAL is a multi-disciplinary open access archive for the deposit and dissemination of scientific research documents, whether they are published or not. The documents may come from teaching and research institutions in France or abroad, or from public or private research centers.
L'archive ouverte pluridisciplinaire HAL, est destinée au dépôt et à la diffusion de documents scientifiques de niveau recherche, publiés ou non, émanant des établissements d'enseignement et de recherche français ou étrangers, des laboratoires publics ou privés. 


\section{Polyheteroaryl Oxazole/Pyridine-based compounds selected in vitro as G-}

\section{quadruplex ligands inhibit Rock kinase and exhibit antiproliferative}

\section{activity}

Daniela Verga ${ }^{\#,}$, Chi-Hung N'Guyen ${ }^{\#, \$}$, Malika Dakir ${ }^{\S}$, Jean-Luc Coll ${ }^{\S}$, Marie-Paule Teulade-Fichou ${ }^{\#, *}$, Annie Molla ${ }^{\S, *}$

\#. "Chemistry, Modelling and Imaging for Biology”, CNRS UMR9187-INSERM U1196, Institut Curie, Research Center Orsay, Bât 110, University Paris-Sud, 91405 Orsay, France

§. Univ. Grenoble Alpes, CNRS UMR 5309, Inserm 1209, CHU Grenoble Alpes, IAB, Grenoble, France

* co-corresponding authors to whom correspondence should be addressed.

$\$$ co-first authors

ABSTRACT: Heptaheteroaryl compounds comprised of oxazole and pyridine units (TOxaPy) are quadruplex DNA (G4)-interactive compounds. Herein, we report on the synthesis of parent compounds bearing either amino side chains (TOxaPy-1-5) or featuring an isomeric oxazole-pyridine central connectivity (iso-TOxapy, iso-TOxapy 1-3) or a bipyridine core (iso-TOxabiPy). The new isomeric series showed significant G4-binding activity in vitro and remarkably 3 compounds (iso-TOxaPy, iso-TOxaPy-1, iso-TOxabiPy) exhibited high antiproliferative activity towards a tumor panel of cancer cell lines. However, these compounds do not behave as typical G-quadruplex binders and the kinase profiling assay revealed that the best antiproliferative molecule iso-TOxaPy selectively inhibited Rock- 2 . The targeting of Rock kinase was confirmed in cells by the dephosphorylation of Rock-2 substrates, the decrease of stress fibers and peripheral focal adhesions, as well as the induction 
of long neurite-like extensions. Remarkably two of these molecules were able to inhibit the growth of cells organized as spheroids.

\section{INTRODUCTION}

G-quadruplexes (G4s) are four-stranded nucleic acid secondary structures formed by repetitive guanosine-rich DNA or RNA sequences. ${ }^{1}$ They are typically formed by four tracts of three guanines with interconnecting loop sequences of variable composition and length. ${ }^{2}$ G4s are found throughout the genome and in mRNA, notably in gene promoters, splicing sites, and telomeres. ${ }^{3}$ Recently, these structures were found enriched in somatic copy number alterations (SCNAs), which are associated to cancer. Precisely, high density of G4 was observed in regions coding oncogenes that specifically relate to $\mathrm{SCN}$ amplifications. ${ }^{4}$ In addition, G4s were described as dynamic genomic structures recruiting helicases and in turn controlling their functions. ${ }^{5-7}$ Consequently, G4s are involved in transcriptional up/downregulation, replication stalling, DNA damage generation, and genome stability. ${ }^{3}$

G-quadruplexes may accommodate small synthetic compounds that could be used as molecular probes to decipher their biological role or as pharmacological agents to block specific functions. ${ }^{8-10}$ More specifically, given that G-quadruplexes are frequently associated with breakpoint regions, telomeric dysfunctions, and repression of oncogene expression, they are considered as druggable targets for cancer therapy. In that sense, a number of G4-binding drugs have shown a broad spectrum of cellular effects that may eventually induce apoptosis and/or senescence in cancer cells (see recent reviews ${ }^{11}$ and $^{12}$ ). The main trends in terms of cellular effects are: i) activation of the DNA damage response in particular at telomeres, ${ }^{13,14}$ ii) synergistic action with DNA repair inhibitors or DNA damaging agents, ${ }^{15-17}$ and iii) downregulation of oncogenes expression in particular c-Myc, c-Kit, K-ras and Bcl2 for a review see. ${ }^{18}$ However, significant differences in cellular effects have been observed so far 
among various classes of G4-ligands which might be due to targeting of different G4 domains, different cellular contexts employed for the experiments, significant off-target effects, and last but not least, chemical diversity of the G4 ligands resulting in differences in their pharmacological properties.

For instance, contrasting data indicates that c-Myc downregulation, by the well-studied G4 ligand quindoline, might result from indirect effects ${ }^{19}$ whereas other G-quadruplex binding ligands regulates gene expression via quadruplex dependent mechanism. ${ }^{20-22}$ In parallel, potential multitargeting of G4-ligands that may affect both DNA and protein activities also appeared in the literature. ${ }^{23}$ Altogether the large body of data on this class of compounds highlights the difficulty to interpret cellular effects in particular in mammalian cells and underlines the necessity of robust target validation.

We previously reported on a new class of acyclic polyheteroaryl compounds, which is comprised of alternate pyridine and oxazole units and binds quadruplexes with high selectivity. ${ }^{24}$ The lead compound of this series TOxaPy exhibits a heptameric scaffold that was shown to adopt a ribbon-like shape likely to favor binding in the groove of quadruplexes as suggested by molecular modeling. This behavior is in line with the selective but moderate G4-binding (low micromolar Kd) and modest stabilizing effect for G-quadruplex structures in vitro. At the cellular level, TOxaPy appeared to be a potent anticancer agent with $\mathrm{IC}_{50}$ values reaching the nanomolar range on a panel of cancer cell lines. ${ }^{24,25}$ However due to its very low solubility in aqueous solution, cellular studies on TOxaPy could not be developed further and thereby prevented establishment of a firm correlation between cellular phenotype and in vitro G4 binding activity. Hence, we decided to launch a program on systematic chemical modifications of the TOxaPy scaffold in the aim of improving solubility and studying in details the cellular effects of this polyheteroaryl series as well as cellular target(s) identification. We were further encouraged in this way by several reports on cationic penta- 
oligoaryls bearing phenyl and oxazole units and somewhat related to the TOxaPy family which were shown to bind G4 in vitro while exhibiting significant antiproliferative activity in several cancer cell lines. ${ }^{26}$ Notably, the authors mentioned difficulties to relate the SAR of this series in cells with the in vitro quadruplex-binding data and interestingly, they pointed out the possible structural analogy with kinases inhibitors containing oxazole scaffolds. ${ }^{26}$

A large panel of modifications was performed to explore structure-activity relationship starting from the TOxaPy scaffold. Firstly to increase the water solubility, amino-terminated alkoxy side chains were grafted on the central pyridine core in the aim of balancing the high lipophilicity of the neutral heptaheteroaryl scaffold (Figure 1, Table 1).

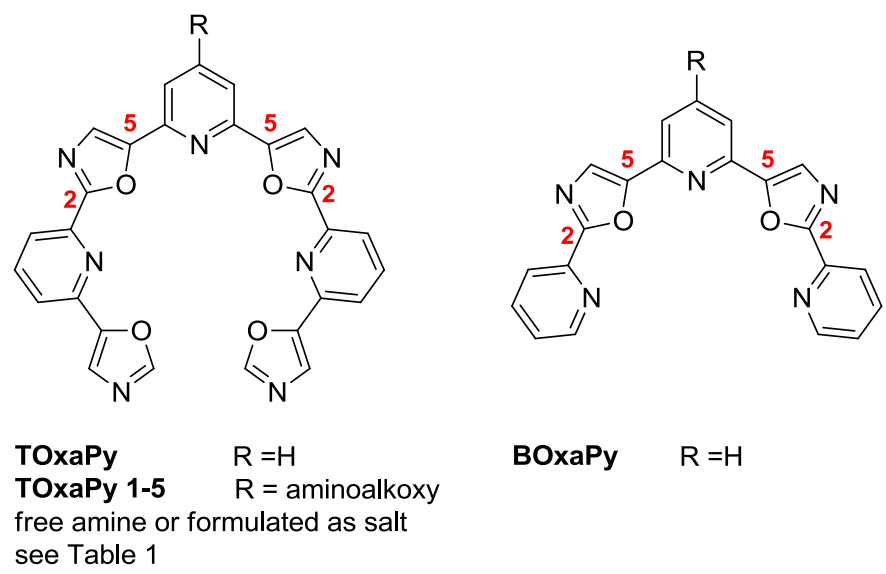

Figure 1. General structure of 7-mer TOxaPy and its cationic derivatives and 5-mer BOxaPy, with a 5,2 oxazole connectivity on the central pyridine core.

Secondly, it was decided to modify the 5,2 connectivity of the oxazole rings on the central pyridine core. Indeed it is been shown that oxazole connectivity significantly impact the solubility and the photophysical properties of an oxazoyl-triphenylamine series when shifting from the 5,2 regioisomer to its 2,5 counterpart. ${ }^{27}$ In addition striking differences in lipophilicity and in pharmacological properties have been observed between regioisomers of oxadiazole-containing drugs, ${ }^{28}$ thereby meaning that connectivity of five-membered rings such as oxazole and oxadiazole on biologically active scaffolds might be a strong determinant 
of activity. Therefore, we synthesized the neutral regioisomer with the inverted 2,5 connectivity, which was coined iso-TOxaPy, as well as a set of 5 aminoalkyloxy substituted counterparts (iso-TOxaPy 1-5, Figure 2 and Table 1). This modification was also carried out on the shorter pentamer that allowed obtaining the iso-BOxaPy family (iso-BOxaPy and isoBOxaPy 1, Figure 2 and Table 1). Although BOxaPy shows no binding to quadruplexes as previously reported, ${ }^{24}$ we evaluated the ability of the neutral regioisomer and its aminoalkyloxy derivative to bind G-quadruplexes, since we demonstrated that grafting cationic side chains on related pentameric oxadiazole compounds could cause significant binding to quadruplexes. ${ }^{29}$ Finally, we were curious to evaluate if the extension of the polyheroaryl scaffold length above seven units would impact or improve the affinity for the DNA target. Therefore, the central pyridine core has been replaced by a bipyridyl moiety while keeping the 2,5 oxazole connectivity, which afforded the octameric compound isoTOxabiPy (Figure2).

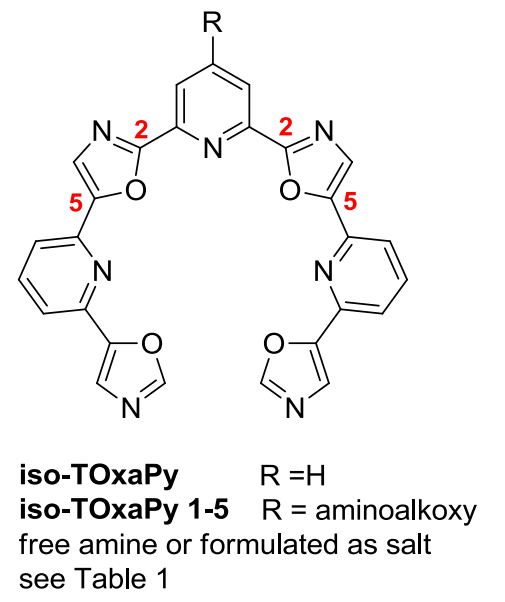

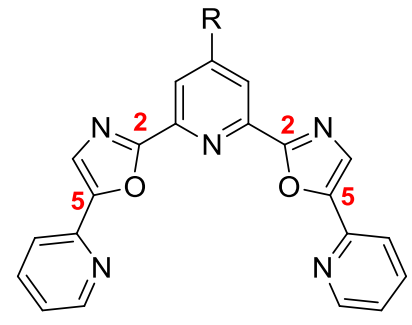

iso-BOxaPy $\quad \mathrm{R}=\mathrm{H}$ iso-BOxaPy $1 \quad \mathrm{R}=$ aminoalkoxy

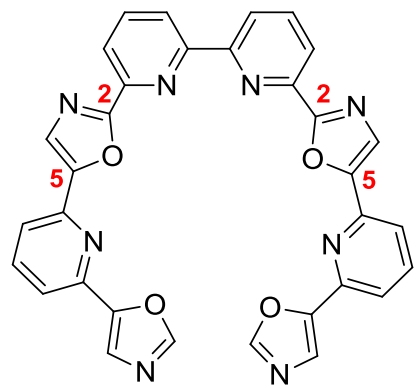

iso-ToxabiPy see Table 1

Figure 2. General structure of the 5-, 7-, and 8-mer regioisomers with a 2,5 oxazole connectivity on the central pyridine or bipyridine core.

Among the new oxazole-based G-quadruplex ligands synthesized, three were selected for their powerful inhibition of cervix cell proliferation. We discovered that these molecules inhibited Rock-2 kinase in vitro and in cellulo. Rho-associated coiled-coil containing kinases 
(ROCK) are effectors of Rho family of small GTPases ${ }^{30}$ and are major regulators of cytoskeletal dynamics, cell contractility, motility, and proliferation. ${ }^{31,32}$ Rho kinase 2 is widely distributed in brain, heart, and muscles, and is overexpressed in certain tumors. ${ }^{33}$ This kinase plays important roles in tumor development and progression through regulating many key cellular functions associated with malignancy, including tumorigenicity, tumor growth, metastasis, angiogenesis, and tumor cell apoptosis/survival. ${ }^{34,35}$ Due to the ability of the synthesized polyheteroaryl oxazole/pyridine to inhibit Rock-2 kinase, they could thus exhibit therapeutic properties. Based on their intrinsic fluorescence, iso-TOxaPy and iso-TOxabiPy were found evenly distributed in the cytoplasm and the nucleus of the cells, and we showed that they efficiently inhibited the growth of cells organized as tissues.

\section{RESULTS AND DISCUSSION}

2.1 Chemistry. TOxaPy, iso-BOxaPy, iso-TOxaPy derivatives, and iso-TOxabiPy (Table 1) were prepared by following multistep synthetic pathways carefully described in this paragraph.

Synthesis of TOxaPy derivatives. TOxaPy derivatives, tethered to solubilizing amino-side chains (Table 1), were synthesized by following a previously published protocol. ${ }^{24}$ The key intermediates of this synthetic pathway are represented by aminoalkyloxytriaryl 5a, b (scheme 1). These dioxazolylpyridines were prepared from diethyl chelidamate $\mathbf{1}$ by employing a four step synthetic protocol: i) Williamson ether synthesis using 2chlorodialkylethanamines and $\mathrm{K}_{2} \mathrm{CO}_{3}\left(72 \%\right.$ and $81 \%$ yield), ii) ester reduction by $\mathrm{NaBH}_{4}$ to give 2,6-dihydroxymethylpyridines 3a, b ( $80 \%$ and $89 \%$ yields), iii) standard oxidation in the presence of $\mathrm{SeO}_{2}$, to afford dicarbaldehydes $4 \mathbf{a}$, b (75\% and 55\% yield), and $\left.i v\right)$ Van Leusen reaction using p-toluenesulfonylmethyl isocyanide (TosMIC) to transform dicarbaldehydes 4a, b in dioxazolylpyridines $\mathbf{5 a}, \mathbf{b}$ ( $40 \%$ and $62 \%$ yields). 5a, b were coupled with 2-bromo- 
6-(1,3-dioxolan-2-yl)pyridine $\mathbf{6}^{24}$ to afford bisacetal precursors $7 \mathbf{a}, \mathbf{b}$ in moderated yields (42\% and $35 \%$ ), which after deprotection provide diformyl compounds $\mathbf{8 a}, \mathbf{b}(62 \%$ and $33 \%$ yields). The formyl groups were finally converted into oxazole moieties after treatment with TosMIC to generate TOxaPy-1 (9a) and TOxaPy-4 (9b) (40\% and 21\% yield).

\section{Scheme 1. Synthesis of TOxaPy derivatives}
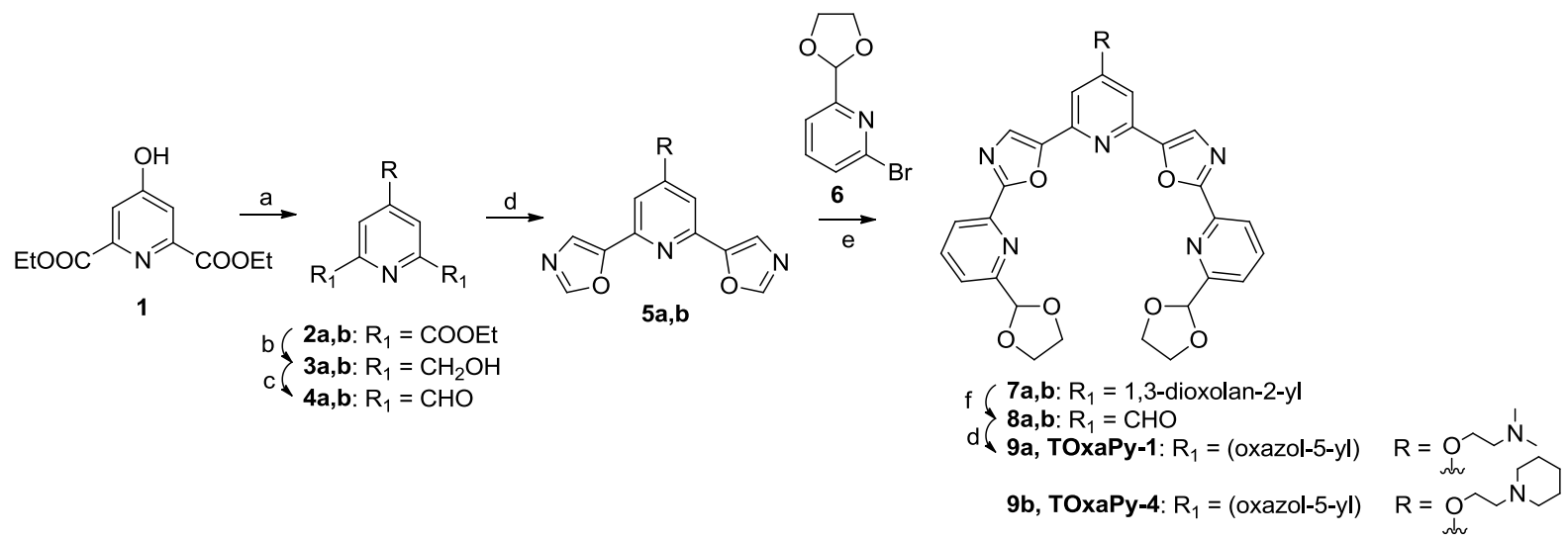

Conditions: (a) chloroamine, $\mathrm{K}_{2} \mathrm{CO}_{3}$, acetone, reflux $18 \mathrm{~h}$; (b) $\mathrm{NaBH}_{4}$, EtOH, $65^{\circ} \mathrm{C}, 18 \mathrm{~h}$; (c) $\mathrm{SeO}_{2}$, 1,4-dioxane, reflux $4 \mathrm{~h}$; (d) p-toluenesulfonylmethyl isocyanide (TosMIC), $\mathrm{K}_{2} \mathrm{CO}_{3}$, EtOH, reflux 2 h; (e) 2-bromo-6-(1,3-dioxolan-2-yl)pyridine, $\mathrm{Pd}(\mathrm{OAc})_{2}, \mathrm{PCy}_{3} \cdot \mathrm{HBF}_{4}, \mathrm{CuI}$, $\mathrm{Cs}_{2} \mathrm{CO}_{3}, 1,4$-dioxane, reflux $20 \mathrm{~h}$; (f) $2 \mathrm{~N} \mathrm{HCl}, 20^{\circ} \mathrm{C}$.

Synthesis of iso-BOxaPy and iso-BOxaPy derivative. The 5-mer regioisomer of BoxaPy (12) was synthesized in a single step as outlined in Scheme 2. Throughout this work, we highlight the formation of aryl-aryl bond based on the palladium-catalyzed cross-coupling previously reported. $^{36}$ By applying the modified method, ${ }^{24}$ the double direct arylation of 2,6dibromopydine 11 with 5-(pyridin-2-yl)oxazole 10 led to the desired iso-BOxaPy in $83 \%$ yield. ${ }^{37}$ Similarly, when dimethylaminoethyloxy pyridine derivative $\mathbf{1 4}$ was used - easily prepared from nitropyridine $\mathbf{1 3}^{38}$ - iso-BOxaPy- $1^{39}$ was isolated with $60 \%$ yield.

\section{Scheme 2. Synthesis of iso-BOxaPy and iso-BOxaPy-1}



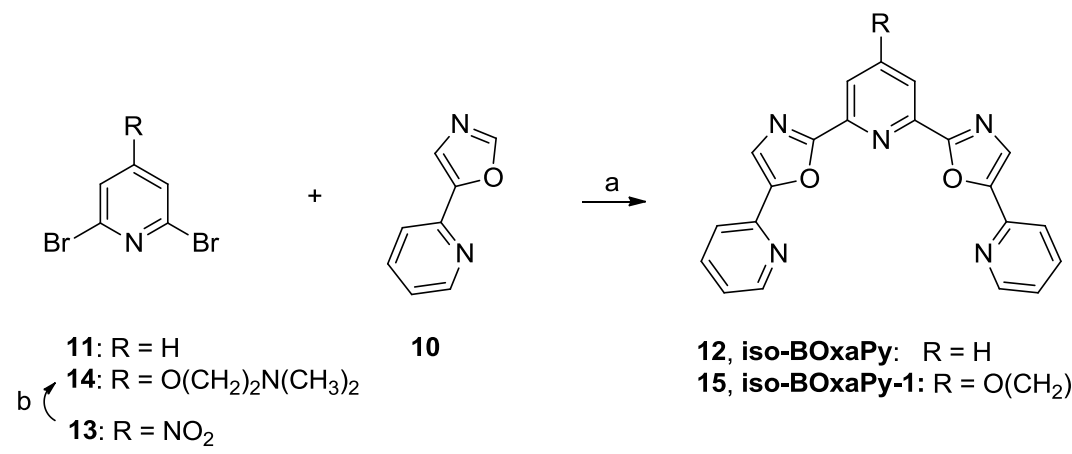

12, iso-BoxaPy: $R=H$

15, iso-BOxaPy-1: $\mathrm{R}=\mathrm{O}\left(\mathrm{CH}_{2}\right)_{2} \mathrm{~N}\left(\mathrm{CH}_{3}\right)_{2}$

Synthetic pathway: (a) $\mathrm{Pd}(\mathrm{OAc})_{2}, \mathrm{PCy}_{3} \cdot \mathrm{HBF}_{4}, \mathrm{CuI}, \mathrm{Cs}_{2} \mathrm{CO}_{3}, 1,4$-dioxane, reflux 18-22 h; (b) 2-(dimethylamino)ethanol, $\mathrm{NaH}, \mathrm{THF}$, room temperature, $3 \mathrm{~h}$.

Synthesis of iso-TOxaPy. The 7-mer regioisomer of TOxaPy was synthesized following two different approaches as outlined in scheme 3. The straightforward pathway (route A) is carried out in a single step and involves the well-known cross coupling using 2,6dibromopyridine $\mathbf{1 1}$ and an excess of triaryl bi-oxazolpyridine $16 .{ }^{24}$ The yield is very low (4\%) due to poly-condensation reactions (Scheme 3, see arrows) occurring between compound 11 and the activated $\mathrm{C}-\mathrm{H}$ bond of 16, thus we developed an alternative method based on a multistep synthetic protocol in order to avoid this problem. Pathway B is based, as well as pathway A, on palladium-catalyzed cross-coupling reaction, but differently from the previous one, uses as key intermediate compound $\mathbf{2 0}$, an oxazolpyridine functionalized with a dioxolan group, instead of the triaryl bi-oxazolpyridine 16. Compound 19 was prepared as previously described ${ }^{40}$ by following a two-step transformation. 2,6-dicarbaldehyde 18 was submitted to acetalization reaction and the generated mono-dioxolane was converted to $\mathbf{2 0}$ by van Leusen reaction. In our hands, the first step was problematic, as the yields did not exceed 20\%. Therefore, we found that by inverting these two steps, we were able to synthesize oxazolpyridine 20 in good yield. Compound 19 was obtained by performing van Leusen reaction in mild conditions $\left(0\right.$ to $\left.20^{\circ} \mathrm{C}\right)$ and higher reaction yields $(34 \%)$ were obtained by employing 0.5 equiv. of TosMIC. By-product bis-oxazolepyridine (16) and starting material $\mathbf{1 8}$ were also isolated respectively in $7 \%$ and $42 \%$ yield. The carbaldehyde function in $\mathbf{1 9}$ was 
protected as acetal with ethylene glycol to generate 20 in $63 \%$ yield. As expected, crosscoupling between dioxolane $\mathbf{2 0}$ and 2,6-dibromopyridine 11 led to penti-aryl intermediate $\mathbf{2 1}$ in good yield (61\%). As mentioned above, iso-TOxaPy (17) was isolated after hydrolysis reaction (84\% yield) and van-Leusen oxazole formation (37\% yield).

\section{Scheme 3. Synthesis iso-TOxaPy}

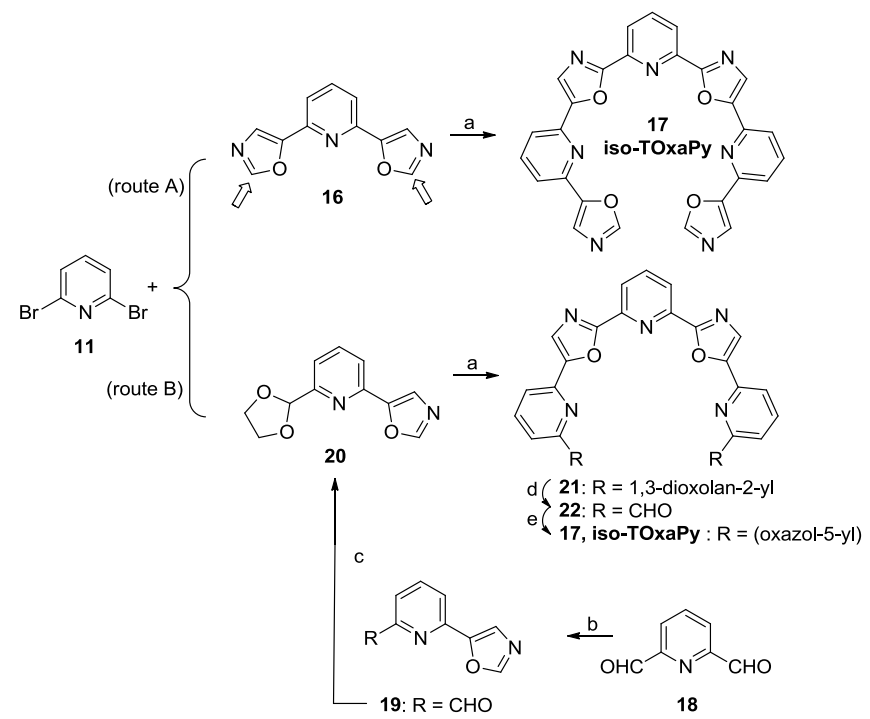

Conditions: (a) $\mathrm{Pd}(\mathrm{OAc})_{2}, \mathrm{PCy}_{3} \cdot \mathrm{HBF}_{4}, \mathrm{CuI}, \mathrm{Cs}_{2} \mathrm{CO}_{3}$, 1,4-dioxane, reflux $22 \mathrm{~h}$; (b) ptoluenesulfonylmethyl isocyanide (0.5 equiv), $\mathrm{K}_{2} \mathrm{CO}_{3}, \mathrm{MeOH}, 0$ to $20^{\circ} \mathrm{C}, 2 \mathrm{~h}$; (c) ethylene glycol, pTsOH, $\mathrm{C}_{6} \mathrm{H}_{12}$, reflux $2 \mathrm{~h}$; (d) $2 \mathrm{~N} \mathrm{HCl}, 110^{\circ} \mathrm{C}, 2 \mathrm{~h}$; (e) p-toluenesulfonylmethyl isocyanide, $\mathrm{K}_{2} \mathrm{CO}_{3}$, EtOH, reflux $5 \mathrm{~h}$.

Synthesis of iso-TOxaPy derivatives and iso-TOxabiPy. Using a similar sequence of reactions, we extended our synthesis to the preparation of 25 (iso-TOxaPy-1) and 29 (iso-TOxabiPy). Cross-coupling reaction between dibromopyridines $\mathbf{1 4}$ or dibromobipyridine $\mathbf{2 6}$ and intermediate $\mathbf{2 0}$ gave respectively biacetals $\mathbf{2 3}$ (36\% yield) and $\mathbf{2 7}$ (71\% yield), which, after deprotection, afforded respectively dialdehydes $\mathbf{2 4}$ (87\% yield) and $\mathbf{2 8}$. The last two were converted into compounds $25(42 \%)$ and 29 (18\% overall yield from biacetal 27) under treatment with TosMIC (Scheme 4). 
Scheme 4. Synthesis iso-TOxaPy derivatives and iso-TOxabiPy

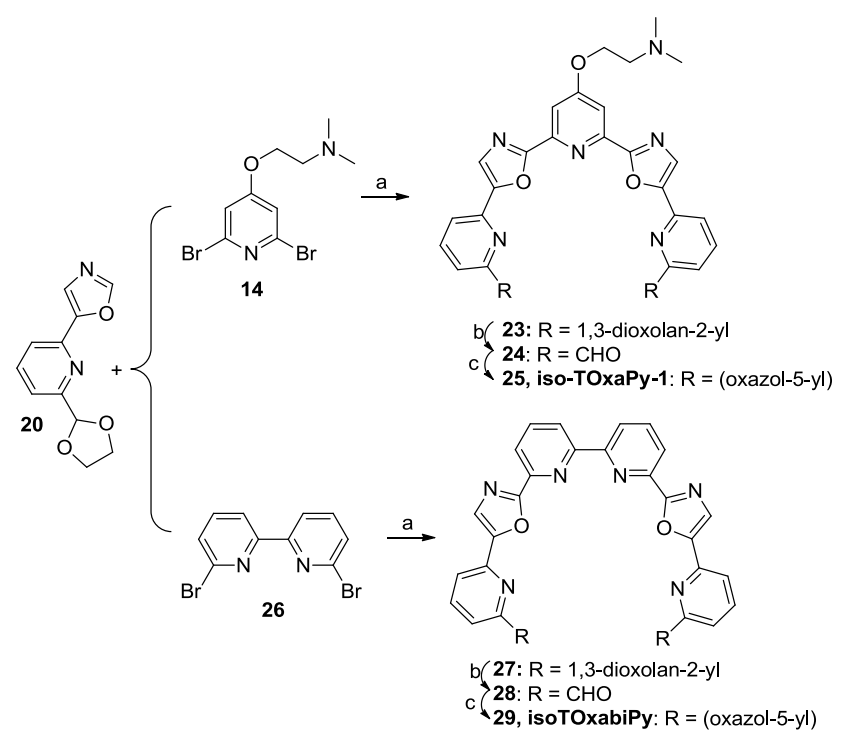

Synthetic pathway: (a) $\mathrm{Pd}(\mathrm{OAc})_{2}, \mathrm{PCy}_{3} \cdot \mathrm{HBF}_{4}, \mathrm{CuI}, \mathrm{Cs}_{2} \mathrm{CO}_{3}, 1$, 4-dioxane, reflux; (b) $2 \mathrm{~N} \mathrm{HCl}$, $20^{\circ} \mathrm{C}$; (c) p-toluenesulfonylmethyl isocyanide, $\mathrm{K}_{2} \mathrm{CO}_{3}$, EtOH, reflux.

Table 1. Structures for TOxaPy, iso-BOxaPy, iso-TOxaPy and their derivatives and isoTOxabiPy. TOxaPy: $\mathrm{A}=\mathrm{C}, \mathrm{B}=\mathrm{N}$, and iso-TOxaPy: $\mathrm{A}=\mathrm{N}, \mathrm{B}=\mathrm{C}$.<smiles></smiles><smiles>[R7]c1cccc(-c2cnc(-c3cccc(-c4cccc(-c5ncc(-c6cccc([R])n6)o5)n4)n3)o2)n1</smiles>

\begin{tabular}{|c|c|c|c|c|}
\hline Compound & $\mathbf{A}$ & B & $\mathbf{R}$ & $\mathbf{R}_{1}$ \\
\hline TOxaPy & $\mathrm{C}$ & $\mathrm{N}$ & $\mathrm{H}$ & \\
\hline TOxаРy-1 & $\mathrm{C}$ & $\mathrm{N}$ & & \\
\hline
\end{tabular}




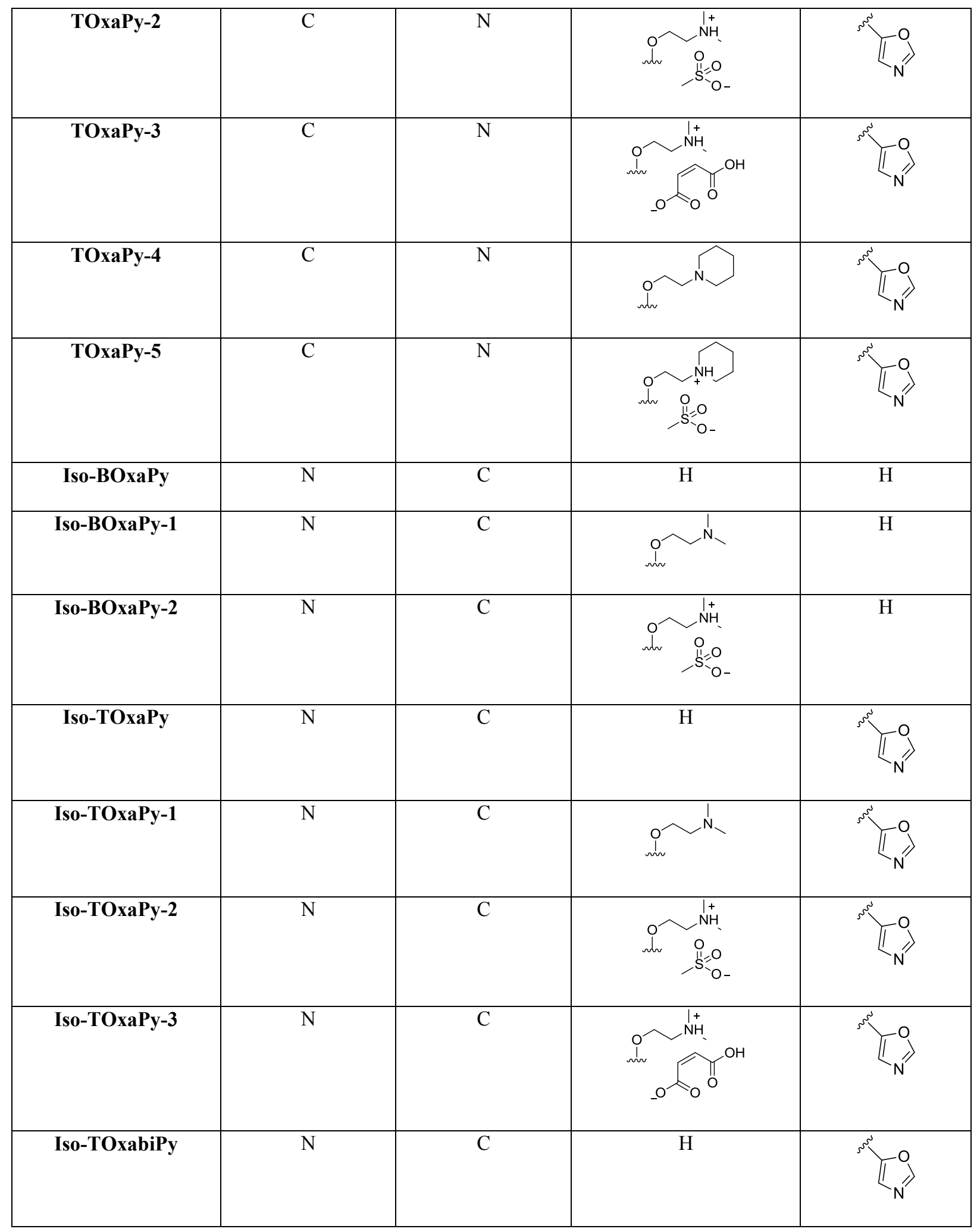

2.2 FRET-melting assay. All the polyheteroaryls compounds were tested for their ability to thermally stabilize sequences apt to form a G-quadruplex structure using the FRET melting assay. In this aim we chose two well-characterized G4 sequences frequently used as 
references for evaluating ligand binding namely the human telomeric sequence (F21T) and the proto-oncogene sequence of c-Myc (FMycT, 22G4T-G23T), each being doubly labeled with fluorophores to enable monitoring thermal denaturation by FRET (Experimental Section, Table 3). As expected from our previous work ${ }^{24}$, the stabilization effects observed $(\Delta \mathrm{Tm})$ are weak to moderate on the telomeric sequence in $\mathrm{K}^{+}$conditions $(10 \mathrm{mM} \mathrm{KCl}, 90 \mathrm{mM} \mathrm{LiCl}, 10$ mM Li cacodylate, Figure 3A). The ligands can be grouped in 3 series: the TOxaPy series (TOxaPy and its cationic derivatives) induces stabilization with $\Delta \mathrm{Tm}$ values ranging from 5-7 ${ }^{\circ} \mathrm{C}$, the iso-BOxaPy series induces stabilization in the range $5-11^{\circ} \mathrm{C}$ and the iso-TOxaPy/ isoTOxabiPy set lies in the range $6-9^{\circ} \mathrm{C}$. One notable trend is the beneficial influence of aminoterminated chains in the 5-mer iso-BOxaPy series in particular on the telomeric sequence, of which the stabilization is significantly enhanced for compounds iso-Boxapy-1,2 $(\Delta \mathrm{Tm}=11$ $\left.11.6^{\circ} \mathrm{C}\right)$ as compared to iso-BOxaPy $\left(\Delta \mathrm{Tm}=5.3{ }^{\circ} \mathrm{C}\right)$. The difference between the two isomeric heptacyclic series TOxaPy and iso-TOxaPy is slight thereby indicating that the inversion of oxazole connectivity has no impact on the ligand binding in these conditions. Altogether the absence of significant difference between the neutral and cationic derivatives and between the 5-mer and the longer 7-mer and 8-mer suggest that the interaction is mainly driven by hydrophobic forces although interaction with the cation present in solution cannot be excluded as has been previously described. ${ }^{24,}{ }^{41}$ Much lower values are observed with the c-Myc sequence in $\mathrm{K}^{+}$buffer $(1 \mathrm{mM} \mathrm{KCl}, 99 \mathrm{mM} \mathrm{LiCl}, 10 \mathrm{mM} \mathrm{Li}$ cacodylate, Figure 3B) for the three series $\left(\Delta \mathrm{Tm}=2.5-4.3{ }^{\circ} \mathrm{C}\right.$ for TOxaPy series, $\Delta \mathrm{Tm}=1.8-2.9^{\circ} \mathrm{C}$ for iso-BOxaPy and 3.4-6. $4^{\circ} \mathrm{C}$ for iso-TOxaPy derivatives). Finally and importantly, the 3 sets of ligands appear all highly selective for quadruplex DNA as compared to duplex DNA as the $\Delta$ Tm values measured are not or poorly affected by the addition of a duplex DNA competitor in excess (Figure S1). 
A)

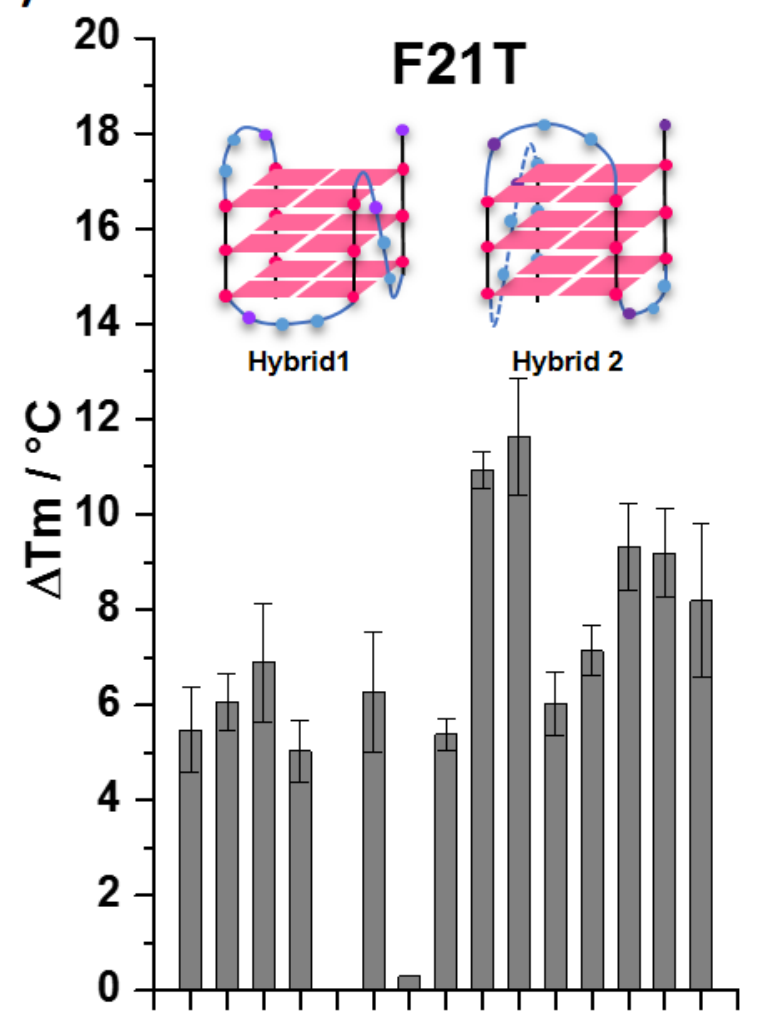

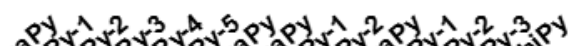

B)

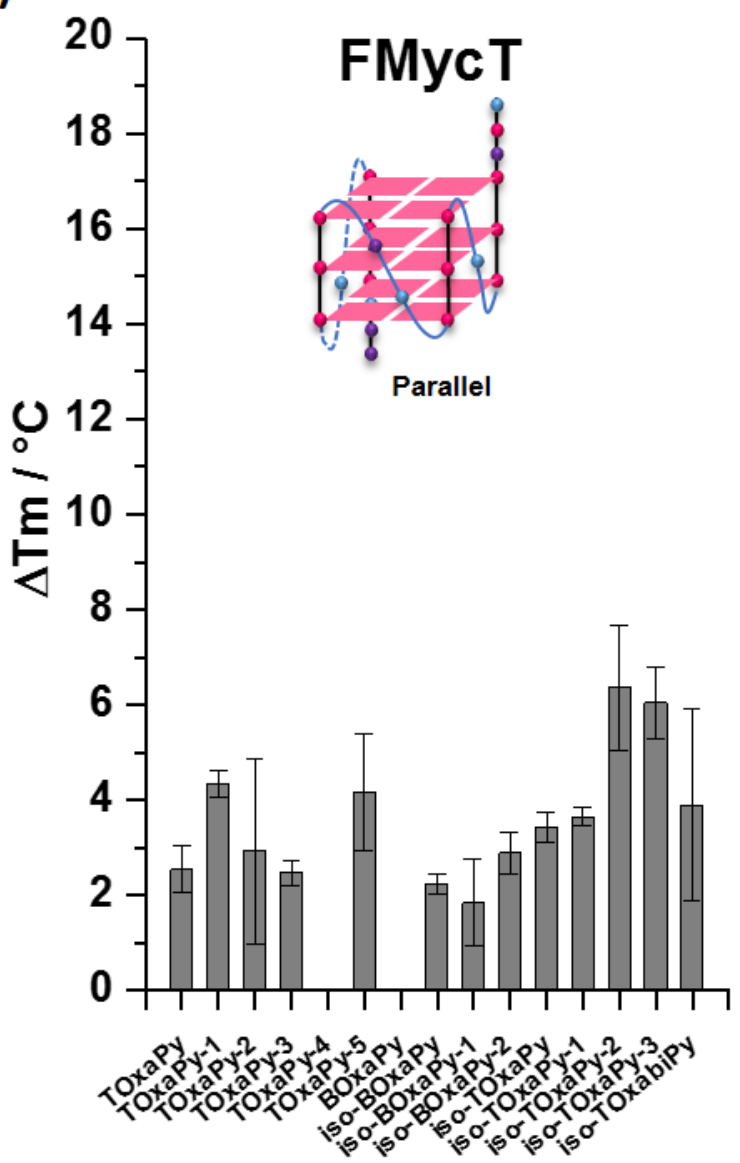

Figure 3. The FRET-melting experiments. Quantitative analysis of the FRET-melting experiments in: $\mathrm{K}^{+}$-rich buffer with the telomeric sequence F21T (A) $10 \mathrm{mM} \mathrm{KCl}, 90 \mathrm{mM}$ $\mathrm{LiCl}, 10 \mathrm{mM} \mathrm{Li}$ cacodylate and the c-Myc oncogene sequence (B) $1 \mathrm{mM} \mathrm{KCl}, 99 \mathrm{mM} \mathrm{LiCl}$, $10 \mathrm{mM} \mathrm{Li}$ cacodylate. The effect of TOxaPy-4 could not be determined due to insufficient solubility. The predominant G4-folds adopted by F21T in $\mathrm{K}^{+}$-buffer (mixture of hybrids) and FMycT (parallel) are represented on the graph.

2.3 Fluorescence titrations. On the aim to gain more understanding on the binding ability and affinity of the new molecules to the G-quadruplex structures, we took advantage of the fluorescence properties of the newly synthesized compounds, which display strong blue fluorescence in buffer solution (Figure S2). We selected three compounds belonging to the family containing oxazoles with 2,5 connectivity, namely iso-TOxaPy, iso-TOxaPy-1, and iso-TOxabiPy, and we carried out fluorescence titrations in the presence of the human 
telomeric and the c-Myc oncogene sequences in $100 \mathrm{mM} \mathrm{KCl}+10 \mathrm{mM}$ Li cacodylate buffer. Interestingly, the addition of G4 DNA induces in all cases a strong concentration-dependent decrease of the fluorescence thereby reflecting strong association between the two partners (Figures S3-S5). Fitting of the titration curves employing a Hill1 equation indicates a 1:1 binding stoichiometry with high apparent binding constant $\left(\mathrm{K}_{\mathrm{a}}\right)$ values lying in the $10^{6}-10^{7} \mathrm{M}^{-}$

${ }^{1}$ range (meaning micromolar to submicromolar $\mathrm{K}_{\mathrm{d}}$ ) (Table 2). These results were quite unexpected especially with c-Myc given the low stabilization effects observed by FRET melting. This suggests that the compounds may indeed display groove-binding interactions or at least interact in a non-typical manner with G4, which is reminiscent of duplex minor groove binders that bind with high affinity but stabilize very poorly duplex DNA. In this case FRET melting might not be the most appropriate assay for the binding affinity evaluation of this series. Finally, the Ka values determined with the duplex model (ds26) show that the 3 derivatives bind roughly with a 2- to 20 -fold preference to G4 structures, iso-TOxaPy being the most selective.

Table 2. Apparent binding constants $\left(K_{a}\right)$ determined from fluorimetric titrations

\begin{tabular}{cccc}
\hline & $\begin{array}{c}K_{a}\left(\mathbf{1 0}^{6} \mathrm{M}^{-1}\right) \\
\text { iso-TOxaPy }\end{array}$ & $\begin{array}{c}K_{a}\left(\mathbf{1 0}^{6} \mathrm{M}^{-1}\right) \\
\text { iso-TOxabiPy }\end{array}$ & $\begin{array}{c}K_{a}\left(\mathbf{1 0}^{6} \mathrm{M}^{-1}\right) \\
\text { iso-TOxaPy-1 }\end{array}$ \\
\hline 22AG.K & 6.7 & 3.9 & 2.5 \\
c-Myc.K & 19 & 16 & 22 \\
ds26 & 0.9 & 3.0 & 1.0 \\
\hline
\end{tabular}

2.4 Cellular cytotoxicity. The synthesized G-quadruplex-binding compounds exhibited different antiproliferative effects on $\mathrm{HeLa}$ cells as shown from the $\mathrm{IC}_{50}$ values (concentration that reduced by two-fold the cell growth) reported in Figure 4A. Compounds TOxaPy-2 and 
iso-BOxaPy-2 produced moderate effects with $\mathrm{IC}_{50}$ values higher than $2 \mu \mathrm{M}$. Differently, TOxaPy-1, iso-TOxaPy-2, and iso-BOxaPy-1 inhibited HeLa growth with $\mathrm{IC}_{50}$ values around $1 \mu \mathrm{M}$, but they were less efficient than iso-TOxabiPy, iso-TOxaPy, and iso-TOxaPy-1. In addition, other synthesized molecules were able to produce effects on cell proliferation at significantly higher concentrations (higher than $5 \mu \mathrm{M}$, data not shown). This first screen clearly indicates that the new isomeric series (iso-TOxaPy derivatives) is more active than the reference series (TOxaPy derivatives) and that the pentamers (iso-BOxaPy1,2) are less efficient than the heptameric counterparts. Finally, the addition of solubilizing chains (isoTOxaPy1-3) does not provide any clear benefit as compared to the neutral derivative (isoTOxaPy). Therefore, the two best candidates (iso-TOxabiPy, iso-TOxaPy), which prevent HeLa cell growth with respective $\mathrm{IC}_{50}$ values of 134 and $257 \mathrm{nM}$, were subsequently tested in a panel of cell lines representative of different cancer types (Figure 4). Although isoTOxabiPy was found slightly more potent than iso-TOxaPy, both affected in a similar way the proliferation of the cells, and interestingly, both molecules prevented the growth of very aggressive glioblastoma (cell line U87) with $\mathrm{IC}_{50}$ values of $246 \mathrm{nM}$ and $440 \mathrm{nM}$ for isoTOxabiPy and iso-TOxaPy, respectively (Figure 4B). ${ }^{42}$ In addition to their action on cervix HeLa cells, they prevented the growth of epidermoid and melanoma cells with $\mathrm{IC}_{50}$ values lower than $0.6 \mu \mathrm{M}$. When we compared the effects produced on two melanoma cell lines, M21 and its variant M21L that lacks av-integrin gene, we observed that the two compounds were less efficient towards M21L known to be the most resistant to chemotherapies. Both compounds failed to inhibit efficiently mucinous (H358) and non-mucinous (A549) lung cancer cell lines $\left(\mathrm{IC}_{50}\right.$ higher than $\left.3 \mu \mathrm{M}\right)$. In conclusion, iso-TOxaPy and iso-TOxabiPy show highly promising antiproliferative properties for restricted but highly promising applications, such as the treatment of resistant cancers. 
A)

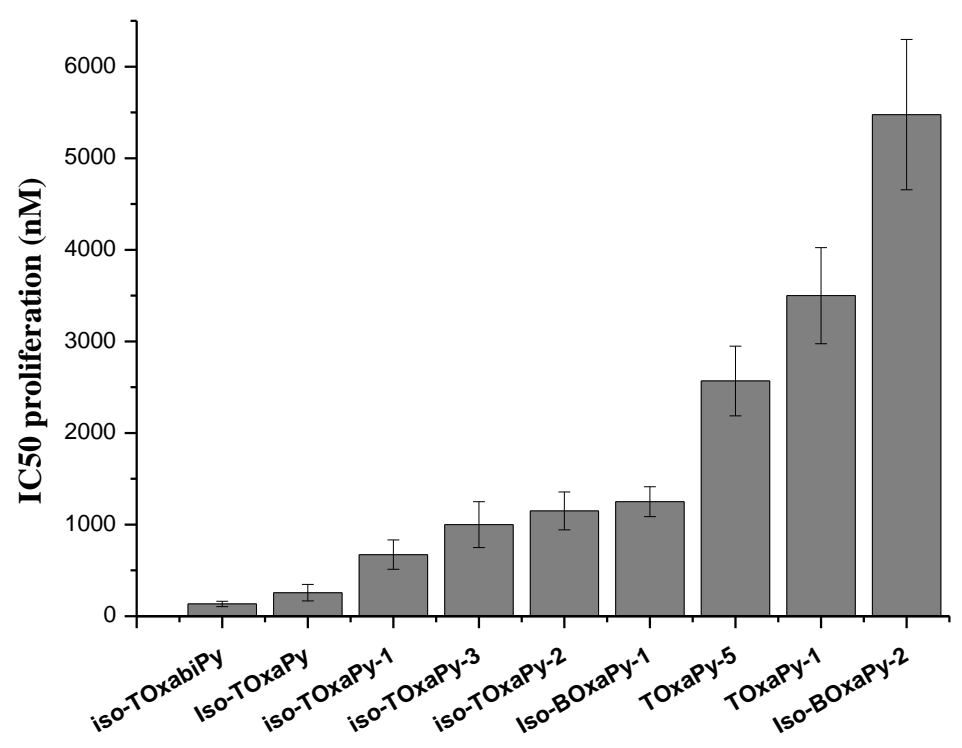

B)

\begin{tabular}{|l|l|l|l|}
\hline \multicolumn{1}{|c|}{ Cellules } & \multicolumn{1}{|c|}{ Type } & \multicolumn{1}{c|}{ Iso-TOxaPy } & \multicolumn{1}{c|}{ Iso-TOxabiPy } \\
\hline A431 & Epidermoid & $645 \pm 64 \mathrm{nM}$ & $541 \pm 163 \mathrm{nM}$ \\
\hline HeLa & Cervix & $257 \pm 90 \mathrm{nM}$ & $134 \pm 30 \mathrm{nM}$ \\
\hline A549 & Lung & $2708 \pm 293 \mathrm{nM}$ & $3950 \pm 598 \mathrm{nM}$ \\
\hline U87 & Glioblastoma & $440 \pm 57 \mathrm{nM}$ & $246 \pm 70 \mathrm{nM}$ \\
\hline Hek293 & Kidney & $457 \pm 81 \mathrm{nM}$ & $\mathrm{ND}$ \\
\hline A375 & Melanoma & $440 \pm 57 \mathrm{nM}$ & $592 \pm 50 \mathrm{nM}$ \\
\hline H358 & Lung & $7700 \pm 900 \mathrm{nM}$ & $3750 \pm 562 \mathrm{nM}$ \\
\hline M21 & Melanoma & $1557 \pm 81 \mathrm{nM}$ & $1577 \pm 430 \mathrm{nM}$ \\
\hline M21L & Melanoma & $7240 \pm 367 \mathrm{mM}$ & $3570 \pm 536 \mathrm{nM}$ \\
\hline
\end{tabular}

Figure 4. Proliferation assays. A) Mean efficiency (in nanoMolar) of different polyheteroaryl compounds towards HeLa cell proliferation, and $\mathbf{B}$ ) $\mathrm{IC}_{50}$ values (in $\mathrm{nM}$ with 
standard deviation data) towards tumor cell lines from different origins treated by iso-TOxaPy or iso-TOxabiPy. ND: not determined.

In order to decrypt their action, we followed cell cycle progression in cells treated with isoTOxaPy or iso-TOxabiPy for $48 \mathrm{~h}($ at $1 \mu \mathrm{M})$. We also evaluated a third compound, isoTOxaPy-1 (at $2 \mu \mathrm{M}$ ), which was ranked at the third position on HeLa cells screen (Figure 4A) and was closely related to iso-TOxapy. The results of FACS (Figure S6A) revealed that nonmajor modifications were induced upon treatment with the three molecules and the cell cycle progression was not affected after two days of treatment. In cells, global targeting of Gquadruplex DNA by G4 ligands generally results in the induction of DNA damages. However in the present case, the detection of histone $\gamma-\mathrm{H} 2 \mathrm{~A}-\mathrm{X}$ with a specific antibody indicated that the three compounds were not DNA-damaging agents either in HeLa cells (Figure S6B), or in A375 melanoma cells (data not shown) after 24 and $48 \mathrm{~h}$ of treatment. Taken together, the lack of detectable DNA damages and the unmodified progression of the cell cycle upon treatment with the three compounds indicate that they do not behave as typical quadruplexinteractive compounds thereby suggesting that G-quadruplex structures may not be their main targets in cells. Altogether this dataset leads to the conclusion that the antiproliferative activity may not result, or at least not solely, from G-quadruplex targeting but most likely involves other cellular pathways.

In the immunofluorescent experiments, meanwhile detecting phospho-histone $\mathrm{H} 2 \mathrm{~A}-\mathrm{X}$, polymerized actin was labeled with phalloidin to easily visualize the cells (Figure S6B). We noticed that the treatment with the three compounds perturbed the organization of stress fibers, which appeared to be less in peripheral regions and more diffuse. Moreover, we observed the presence of large vesicles in the cytoplasm of resistant cell lines, like A549 cells, following treatments with the same derivatives (data not shown). The phosphoinositide lipid $\mathrm{PI}(4,5) \mathrm{P}_{2}$ is now established as a key cofactor in signaling to the actin cytoskeleton and in 
vesicle trafficking, ${ }^{43}$ all together these two sets of data led us to hypothesize that these compounds could inhibit lipid kinases.

To identify the targeted kinase, a profiling assay was carried out and the three compounds were tested in vitro towards 15 key lipid kinases (Figure S7A). Most of the lipid kinases employed for the screening were not affected by the presence of the compounds at $1 \mu \mathrm{M}$ concentration. However, we noticed a slight decrease in activity for three class 1 Pi3-kinases (PI3K), especially upon treatment with iso-TOxaPy (Figure S7A). This result, although very modest, prompted us to challenge iso-TOxabiPy, the most active compound in cell assays, against a series of 50 enzymes that provide a representative sampling of the human kinome (Figure S7B). iso-TOxabiPy inhibited specifically kinase Rock-2 by $70 \%$ at $1 \mu \mathrm{M}$, while the 49 other enzymes were not affected (Figure S7B). The interesting result obtained with isoTOxabiPy prompted us to test the three active compounds on 3 kinases belonging to the Rock family (Rock-1, -2, and DMPK). Table 3 shows $\mathrm{IC}_{50}$ values related to the 3 compounds, and interestingly, all of them are potent inhibitors of Rock- 2 with $\mathrm{IC}_{50}$ values ranging from nanomolar concentration for iso-TOxaPy, iso-TOxaPy-1 (29 nM and $20 \mathrm{nM}$ respectively) to submicromolar concentration for iso-TOxabiPy $(851 \mathrm{nM})$. Even more remarkable, the three compounds are much less efficient with regard to the two other kinases $\left(\mathrm{IC}_{50}>\mu \mathrm{M}\right)$. This selectivity is particularly high for iso-TOxaPy and iso-TOxaPy-1 with a factor superior to 50 whereas it is more modest for iso-TOxabiPy with a factor of 1.4 (Table 2). A competition assay was run in the presence of iso-TOxaPy at the concentration of $100 \mathrm{nM}$ and in the presence of 5 different ATP-concentrations, revealing that this molecule is an ATP competitive inhibitor (Figure S7C). Proteins Rock-1 and -2 have 87\% sequence homology in their ATP binding site but differs in their coiled-coil Rho-binding domain. ${ }^{44}$ This observation is in line with the behavior of already reported Rock inhibitors that were also described to preferentially target Rock-2 over the other Rock kinase members, suggesting an easier 
accessibility of the Rock-2 ATP-binding site as compared to the others. ${ }^{45}$ Finally the $\mathrm{IC}_{50}$ values and the determined selectivity indicate that iso-TOxaPy and iso-TOxaPy-1 may rival with the best inhibitors of Rock kinase reported so far. ${ }^{45}$

Table 3. In vitro, Rock kinase inhibition.

Mean concentrations of inhibition $\left(\mathrm{IC}_{50}\right)$ determined for iso-TOxaPy, iso-TOxaPy-1, and isoTOxabiPy within the rock family (Rock-1, Rock-2 and DMPK). DMPK: Dystrophia myotonica protein kinase or myotonic dystrophy protein kinase.

\begin{tabular}{|l|l|l|l|}
\hline \multicolumn{1}{|c|}{ Kinase } & \multicolumn{1}{|c|}{ iso-TOxaPy } & \multicolumn{1}{c|}{ iso-TOxaPy-1 } & \multicolumn{1}{c|}{ Iso-TOxabiPy } \\
\hline Rock-1 & Sup $1 \mu \mathrm{M}$ & Sup $1 \mu \mathrm{M}$ & Sup $1 \mu \mathrm{M}$ \\
\hline Rock-2 & $\mathbf{2 9} \pm \mathbf{2 n M}$ & $\mathbf{2 0} \pm \mathbf{5 n M}$ & $\mathbf{8 5 1} \pm \mathbf{5 0 n M}$ \\
\hline DMPK & Sup $1 \mu \mathrm{M}$ & Sup $1 \mu \mathrm{M}$ & Sup $1 \mu \mathrm{M}$ \\
\hline
\end{tabular}

These in vitro results (iso-TOxaPy $=$ iso-TOxapy- $1>$ iso-TOxabipy) did not fit with the hierarchy emerging for the three compounds from proliferation data (iso-TOxabipy $>$ isoTOxaPy $>$ iso-TOxaPy-1), however the targeting of Rock was consistent with the observed disorganization of stress fibers (Figure S6B). Therefore, we decided to analyze more carefully the effect of the three derivatives on the organization of the cytoskeleton by fluorescence detection of actin and tubulin (Figure 5). 

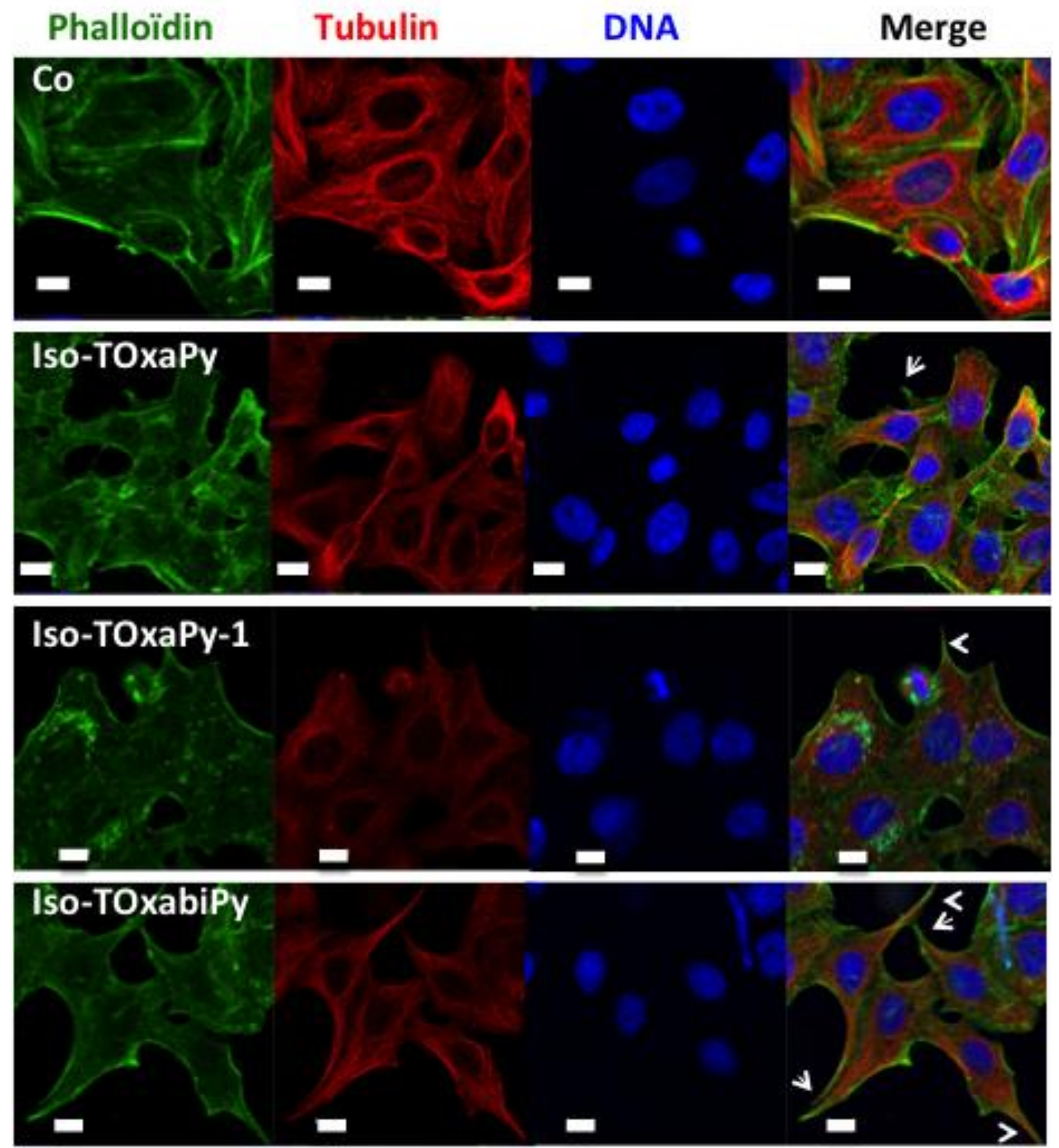

Figure 5. Organization of the cytoskeleton in the presence of iso-TOxaPy analogues. Immunofluorescence of HeLa cells under control conditions (Co) or upon iso-TOxaPy analogue treatment $(\mathrm{ON}, 2 \mu \mathrm{M})$. Actin, $\alpha$-tubulin, and DNA are simultaneously detected. Phalloidin-labeled actin is in green and $\alpha$-tubulin is in red whereas DNA is in blue. The bar represents $10 \mu \mathrm{m}$. Respective treatments are indicated on the left. White arrows point cell extensions. 
In control conditions, cells spread over the substrate and nice stress fibers were decorated by phalloidin (Figure 5-Co). Differently, cells incubated with the compounds had a limited spreading and long neurite-like extensions appeared (Figure 5, see arrows). In addition, we noted the presence of short actin fibers mostly not present in control conditions. Moreover, the microtubule network appeared less developed probably as consequence of a reduced cell spreading (note the differences around the nuclei). Afterwards, we detected the focal contacts with a phospho-tyrosine antibody (Figure 6), phospho-tyrosine being a convenient marker of focal adhesions. This signal is associated with the formation of these structures and appears when integrin is engaged. The two main phospho-proteins identified are the FAK (focal adhesion kinase) and paxillin. ${ }^{46}$ Large and numerous focal adhesions were detected in control conditions (Figure 6, see the zoom on the right part), on the other hand, in cells treated either by iso-TOxaPy, iso-TOxaPy-1, or iso-TOxabiPy, phospho-tyrosine was highly present at the tip of the extensions when other focal contacts were smaller than in control. Among the three compounds, iso-TOxabiPy seemed the most efficient and the localization of focal contacts was also less peripheral than in the control. A similar observation was observed when cells were incubated in the presence of Y-27632, a Rock kinase inhibitor used as a reference. All together, these immunofluorescence data confirmed that the oligoaryl compounds targeted Rock kinases in cells, since we observed the typical cellular response of Rock inhibition - i.e., a limited cell spreading and the induction of long neurite-like extensions. Phospho-tyrosine was highly present in the tips of these extensions whereas other focal contacts were small and less peripheral than in the control. Moreover, several mitotic cells (metaphase, telophase) were present in the imaged fields, independently on the treatment, thus confirming that the cell cycle progressed in the presence of the drugs. 

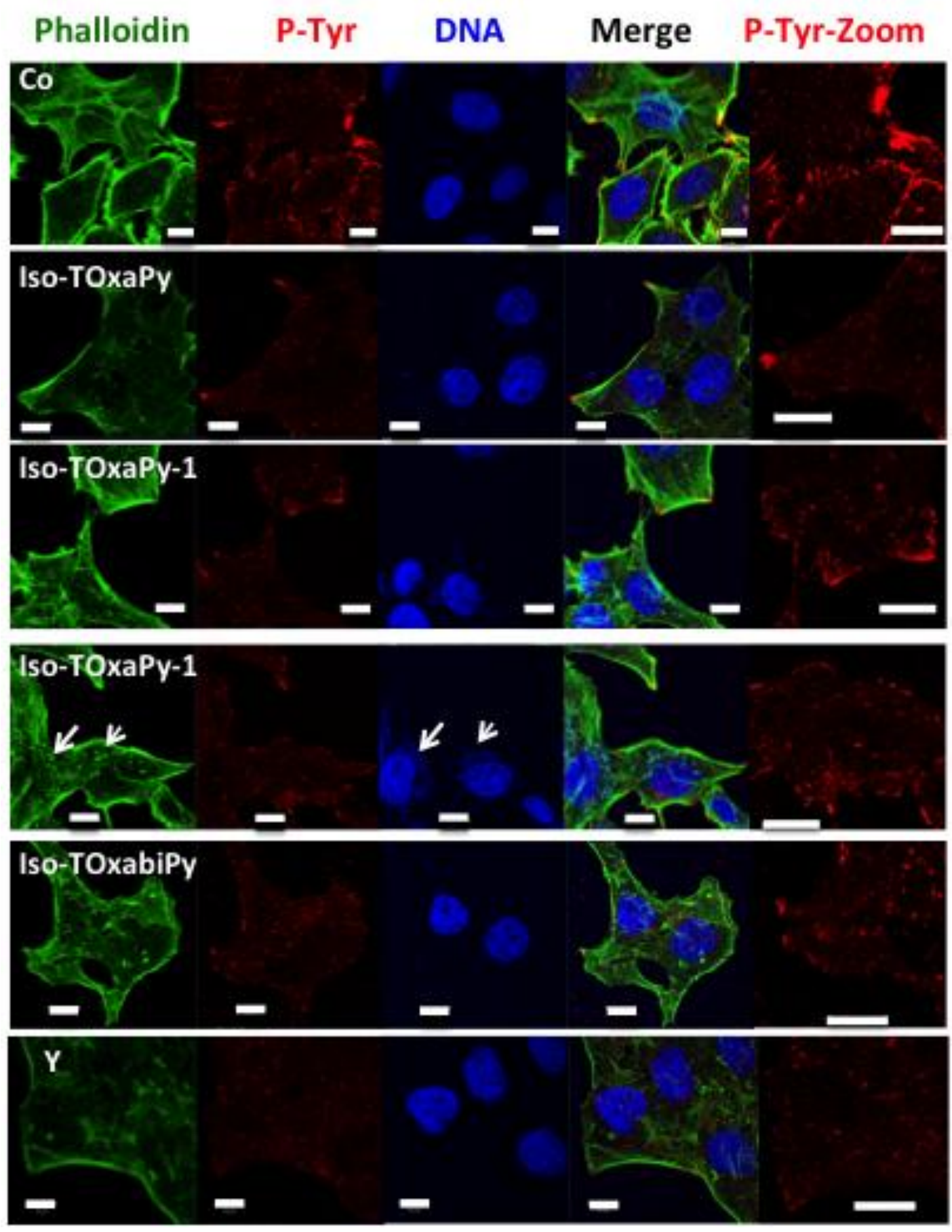

Figure 6. Organization of the cytoskeleton in the presence of iso-TOxaPy analogues. Immunofluorescence experiments of HeLa cells under control conditions (Co) or upon isoTOxaPy analogue treatment $(\mathrm{ON}, 2 \mu \mathrm{M})$ : detection of phalloidin-labeled actin is in green. The focal points are decorated by an anti-P-Tyr antibody (in red), DNA is in blue. The bar represents $10 \mu \mathrm{m}$. The right panel represents a two-fold zoom of the P-Tyr signal. Treatments 
are indicated on the left and Y stands for Y-27632, a known rock kinase inhibitor. The arrows point an additional signal in comparison to other conditions that could be attributed to isoTOxaPy-1.

In order to confirm the rock-2 targeting in cells, we detected a rock-2 substrate: phosphoMYPT1-Thr $853^{47}$ (Figure 7A) and a down-stream target: phospho-Cofilin-Ser3 (Figure 7A). Cofilin is phosphorylated by Lim-kinase, itself activated by rock phosphorylation. ${ }^{48} \mathrm{We}$ detected the phospho-proteins in HeLa cells by immunofluorescence upon 3 hours of treatment. As control conditions, we imaged HeLa cells in the absence of treatment and in the presence of Y-27632. For phospho-MYPT1, we observed a clear decrease of the cytoplasmic phospho-signal and a slight decrease in the nucleus and in mitotic cells upon treatment by either iso-TOxaPy or iso-TOxabiPy (Figure 7A). The treatment by iso-TOxaPy-1 gave rise to a punctuated signal that will be analyzed thereafter. Treatment by either iso-TOxaPy or isoTOxabiPy decreased significantly the phosphorylation of Cofilin (Figure 7B, 7C). The immuno-blott detecting phospho-Cofilin confirms that isoTOxabiPy is the more potent rock-2 inhibitor in cells and iso-TOxaPy-1 the less efficient (Figure 7C). These results fit with the observed morphology of the cells upon treatment (Figure 5,6) and confirm the rock targeting by these compounds (Figure 7). 

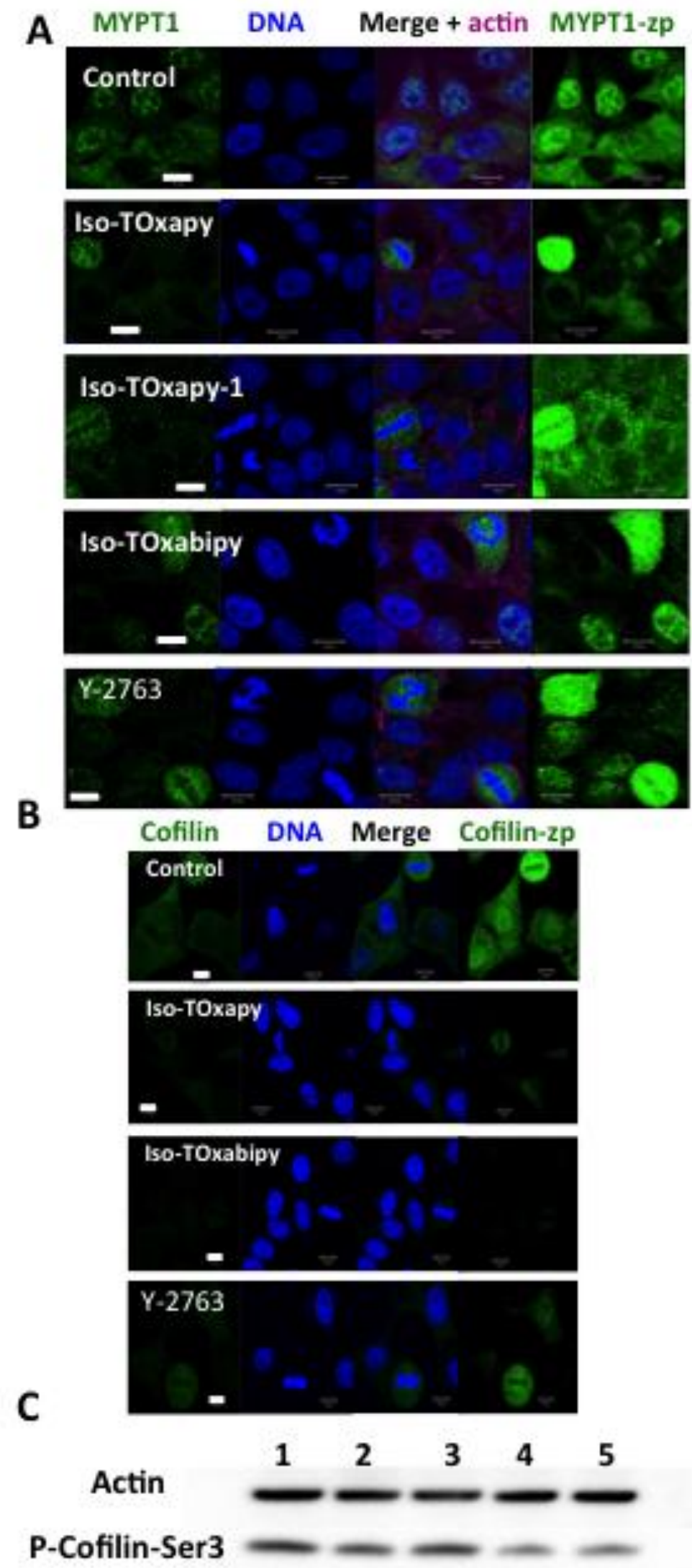
Figure 7. Detection of the phosphorylation of Rock substrates. Immunofluorescence of HeLa cells under control conditions (Co) or upon iso-TOxaPy analogue treatments $(3 \mathrm{~h}$ at 2 $\mu \mathrm{M}$ for iso-TOxaPy and iso-TOxabiPy, and $5 \mu \mathrm{M}$ for iso-TOxapy-1). The set-up was established for the control and then unmodified for the corresponding assays. PhosphoMYPT1 was detected in A and phospho-Cofilin in B, both appear in green. DNA is simultaneously detected as well as actin in A. Confocal slices are shown and a projection of the whole fluorescence is presented on the right (MYPT1-zp and Cofilin-zp), which allows a direct visualization of the phospho-signal. Respective treatments are indicated on the left and Y-27632 is a known rock kinase inhibitor. The bar represents $10 \mu \mathrm{m}$. In $\mathbf{C}$, whole cell extracts were analyzed by western blotting. Actin and phospho-Cofilin-Ser3 were detected on the same membrane. Control is in lane 1, cells treated by iso-TOxaPy, iso-TOxaPy-1, isoTOxabiPy, and Y-2763 are respectively in lanes 2, 3, 4 and 5.

On the immunofluorescence images, we noticed an additional fluorescent signal in cells treated by iso-TOxaPy-1. As observed in Figures 6 and 7, a green and blue fluorescent dot signal appeared (see the color arrows in Figure 6) after treatment with iso-TOxaPy-1 due to the intrinsic fluorescence of the compound, as shown by the recorded spectra (Figure S2). Thus, we decided to image the treated HeLa cells in the absence of any fluorophore (Figure $8 \mathrm{~A}$ and $8 \mathrm{C}$ ). The basal level of fluorescence of HeLa cells, recovered around $510 \mathrm{~nm}$, was shown in the control (Figure 8A-Co). When cells were incubated with iso-TOxaPy-1, a fluorescent signal was detected in comparison to control cells and it appeared mostly as big dots present throughout the cytoplasm and mostly concentrated around the nucleus (Figure 8A, compare [Control +] and [iso-TOxaPy-1 +]). As expected, this fluorescent signal could also be imaged with a $405 \mathrm{~nm}$ excitation (Figure $8 \mathrm{C}$ ). Furthermore, when the cells were incubated in the presence of either iso-TOxaPy or iso-TOxabiPy, a weak fluorescent signal is 
detected following a $488 \mathrm{~nm}$ excitation but it appeared evenly distributed in the cytoplasm and the nucleus (Figure 8A).

In these images, we again observed that cell spreading was reduced and long projections appeared following iso-TOxaPy and iso-TOxabiPy treatments. The presence of iso-TOxaPy and iso-TOxabiPy in the nucleus could be consistent with their in vitro G-quadruplex-DNA binding properties. Therefore, the absence of typical response characterizing G-quadruplex targeting in cells cannot be attributed to a poor diffusion to the nucleus and could probably be accounted for a poor accessibility of these compounds to G4 forming domains in the context of chromatin. Moreover, the deficit of cellular activity of iso-TOxaPy-1 compared to its in vitro capacity could be attributed to its trapping in dots that could be cellular vesicles. This difference as compared to the iso-TOxaPy analogue might be due to the presence of the additional cationic amino side chain that should modulate the solubility and the intracellular behavior of the compound. In cells only a minimum amount of iso-TOxaPy-1, below the efficient concentration, was detected free in the cytoplasm especially at focal contacts where Rock kinases are active. 


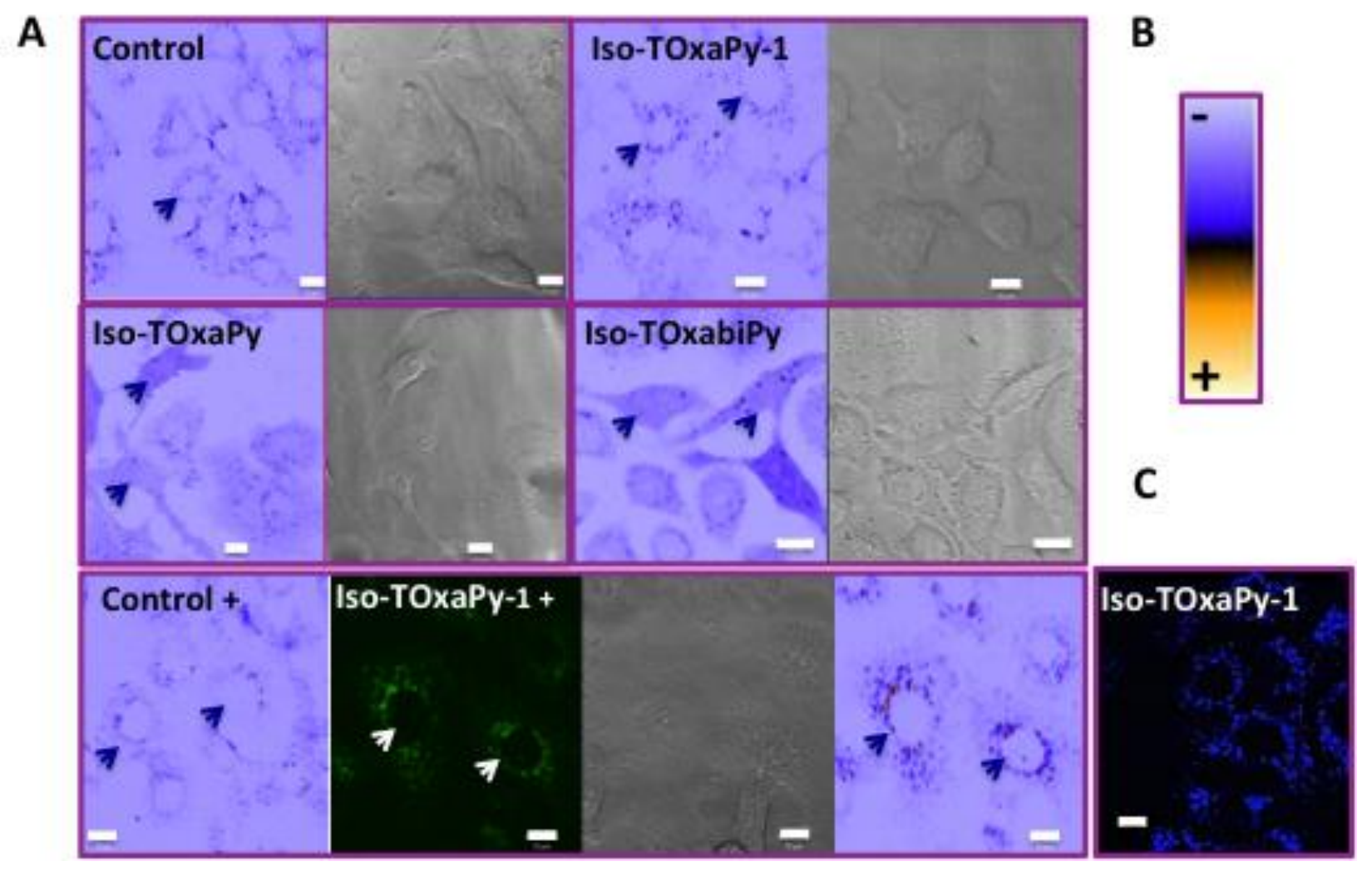

Figure 8. Detection of the compounds by their intrinsic fluorescence. A) HeLa cells treated for $17 \mathrm{~h}$, in the presence of the compounds $(2 \mu \mathrm{M}$ for iso-TOxaPy and iso-TOxabiPy, and $3.3 \mu \mathrm{M}$ for iso-TOxaPy-1) are imaged, with excitation wavelength at $488 \mathrm{~nm}$, in the absence of any additional fluorophore. For a better visualization, the green signals are turned to a rainbow false color (scale shown in B). The corresponding wide fields allow visualizing the nucleus and the cell border. [iso-TOxaPy-1 +] and [control +] indicate that the power laser was increased compared to upper images. The bright field and the green signal correspond to the iso-TOxaPy-1+ treatment. Arrows point to nucleus. B) Rainbow blue to orange scale used to better visualizing the fluorescence in B. C) The cells treated with iso-TOxaPy-1 (3.3 $\mu \mathrm{M})$ were imaged following a $405 \mathrm{~nm}$ excitation. In B and C, the bar represents $10 \mu \mathrm{m}$.

These data illustrated the difficulties to anticipate the activities of molecules in cells, on the basis of in vitro experiments. However, the possibility to follow the distribution of this series 
of compounds in cells by fluorescence detection was a clear advantage and a crucial point for understanding and rationalizing their respective potential and activities.

Up to this point, the effects of the molecules were studied on cells grown as a monolayer and we decided to investigate the effects of the compounds on 3D cultures, because they are better predictive for therapeutic applications. Thus we challenged HeLa spheroid cultures with the three molecules. Each derivative was tested at four different concentrations and the expansion of the spheroid was followed day by day (Figure 9). A representative spheroid is shown in each series and the average surface areas are plotted on the graphs (Figure 9B). iso-TOxabiPy and iso-TOxaPy inhibited efficiently the growth of the cells organized in $3 \mathrm{D}$ even at the lowest concentration tested ( $300 \mathrm{nM}$ and $570 \mathrm{nM}$ respectively), suggesting that they entered in the interstitial space. Conversely, iso-TOxaPy-1 failed to prevent spheroid growth and a decrease of only $25 \%$ of the surface was observed at $4 \mu \mathrm{M}$, at day 7 . 


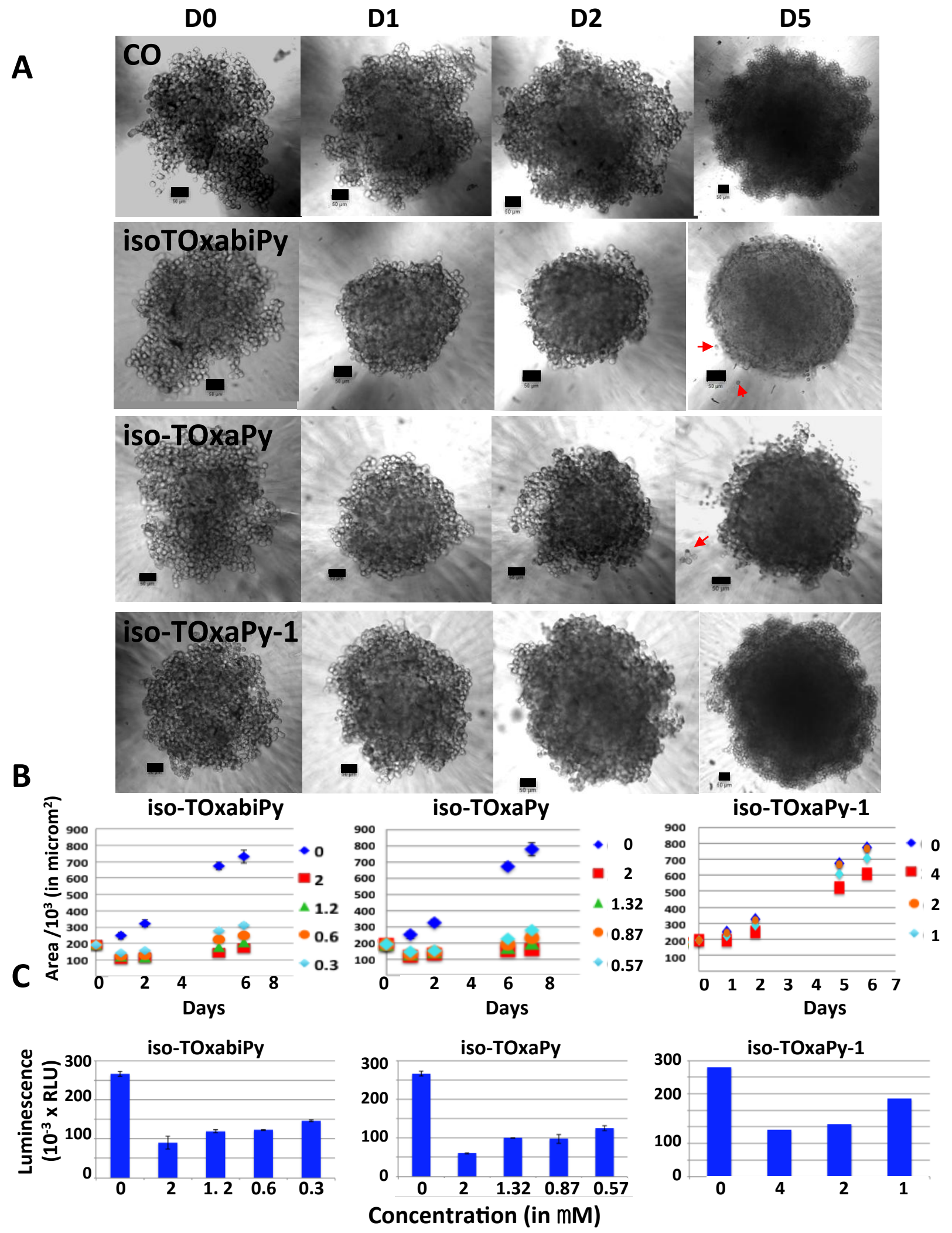

Figure 9. Efficiency of iso-TOxaPy analogues on affecting cells grown as spheroids (3D cultures). A) HeLa cells were grown as 3D spheroids and their expansion was followed by 
microscopy. The maximal surface was measured each day for each spheroid ( 5 in each assay). A representative spheroid of each treatment is shown at days 0 (addition of the drug) and at days 1, 2 and 5. Treatments are listed on the left and Co means control. A black size bar of 50 $\mu \mathrm{m}$ is indicated on each photo and the red arrows point cell escaping from the spheroid. B) Quantification of the experiment presented in A. Data are the mean of 5 determinations. Four different concentrations of compounds were tested (from $1 \mu \mathrm{M}$ to $4 \mu \mathrm{M}$ for iso-TOxaPy-1, from $0.57 \mu \mathrm{M}$ to $2 \mu \mathrm{M}$ for iso-TOxaPy, and from $0.3 \mu \mathrm{M}$ to $2 \mu \mathrm{M}$ for iso-TOxabiPy). C) Quantification of the ATP content of the cells within the different spheroids at the end-point (day 6 post addition of the drug) by bioluminescence. The different concentrations of compounds (in $\mu \mathrm{M}$ ) are indicated under each histogram.

These data were confirmed at the end point by measuring the ATP content, which reflected the proportion of live cells (Figure 8C). Both area measurements and ATP contents varied in parallel (Figure 9B and 9C). Treatment of the 3D cultures with iso-TOxaPy and iso-TOxabiPy induced a few cells to escape from the spheroid and pack together. This feature was never previously observed and could therefore be specific of the mode of action of the present molecules able to inhibit Rock-2. ${ }^{49}$ The inhibition of Rock induced a defective spreading and cells escaped from the spheroids but this might not be a negative point, since individual cell re-aggregated to form smallest organoids.

\section{Conclusion}

In conclusion, we synthesized a new series of oxazole/pyridine based oligomeric compounds that are able to bind and stabilize G-quadruplex structures in vitro, but that seem unable to massively target G-quadruplex structures in cells; however, the possibility that they could modify long-term transcriptional regulation or specific genes was not investigated. 
Interestingly, we discovered that iso-TOxaPy targeted specifically Rock-2 kinase in vitro and in cells, and iso-TOxaPy and iso-TOxabiPy are potent cell growth inhibitors in 2D as well as in $3 \mathrm{D}$ cultures and exhibit potency in a large panel of tumors. Although these oligoheteroaryl derivatives are quite hydrophobic and display rather poor solubility in aqueous media, their flexible oligomeric scaffolds, which can adopt a large variety of conformations, may be beneficial to circulate within an organoid and affect its expansion. The latter represents an encouraging feature for tumor treatment applications. These derivatives represent a new chemical family able to act as effector of the Rho family of small GTPases, essential signaling proteins involved in cytoskeleton organization. In addition to cancer treatment, Rock-2 are involved in several pathologies like cardiovascular disease, ocular and systemic disorders. Therefore, this iso-TOxaPy series holds great promise as new prototype for future development of drugs with a broad spectrum of therapeutic applications. In addition, the strong specificity of the compounds for the Rock-2 over Rock-1 isoform might have the advantage of inducing fewer side effects. ${ }^{45}$

\section{Experimental Section}

4.1 Chemical Synthesis. All chemicals were purchased from Sigma-Aldrich. All the solvents were obtained from VWR. Melting points were taken on a Köfler melting point apparatus and are uncorrected. TLC analysis was carried out on silica gel or on neutral aluminium oxide (Merck 60F 254 ) with visualization at 254 and $366 \mathrm{~nm}$. Flash chromatography was performed with silica gel 60 (40-63 $\mu \mathrm{m}$, Merk) or neutral alumina 90 (63-200 $\mu \mathrm{m}$, Merk). All anhydrous reactions were carried out under positive pressure of nitrogen or argon. Elemental analyses were provided by the CNRS microanalysis service I.C.S.N (Institut de Chimie des Substances Naturelles, Gif-sur-Yvette, France). Deuterated $\mathrm{CDCl}_{3}$ and DMSO- $d_{6}$ were purchased from SDS. All ${ }^{1} \mathrm{H}$ NMR and ${ }^{13} \mathrm{C}$ NMR spectra were recorded on a Bruker Advance $300 \mathrm{MHz}$ spectrometer using deuterated solvents and TMS as internal standard. The spectra are reported 
in ppm and referenced to deuterated DMSO (2.49 $\mathrm{ppm}$ for ${ }^{1} \mathrm{H}, 39.5 \mathrm{ppm}$ for $\left.{ }^{13} \mathrm{C}\right)$ or deuterated chloroform (7.26 ppm for ${ }^{1} \mathrm{H}, 77 \mathrm{ppm}$ for $\left.{ }^{13} \mathrm{C}\right)$. The following abbreviations are used: singlet $(\mathrm{s})$, doublet $(\mathrm{d})$, triplet $(\mathrm{t})$ and multiplet $(\mathrm{m})$. All compounds were analyzed for purity by HPLC using either MS or UV absorbance detectors. Low resolution mass spectrometry (ESIMS) was recorded on a micromass ZQ 2000 (waters). Analytic reversed phase liquid chromatography (RP-HPLC) was performed using a Waters Alliance unit and a XBridge C18 $3.5 \mu \mathrm{m} 3.0 \mathrm{x} 100 \mathrm{~mm}$, column (Waters) was used. Gradient HPLC injection: flow $0.75 \mathrm{~mL} / \mathrm{min}$; gradient elution: eluent $\mathrm{A} \% \mathrm{H}_{2} \mathrm{O}$ 0.1\% FA (formic acid), eluent $\mathrm{B} \% \mathrm{MeCN}$ 0.1\% FA: 0 min (98/2), $1 \min (98 / 2), 7 \min (0 / 100), 9 \min (0 / 100), 13 \min (98 / 2)$. All final compounds showed $\geq 95 \%$ purity. Oligonucleotide sequences were purchased from Eurogentec. FRETmelting assay were performed in 96-well plates on real time PCR apparatus 7900HT Fast Real-Time PCR System.

4.1.1 Synthesis of TOxaPy derivatives. The synthesis of TOxaPy derivatives was performed following a multistep synthetic pathway described in the subsequent protocols.

Diethyl 4-(2-(dimethylamino)ethoxy)pyridine-2,6-dicarboxylate 2a. Compound 1 (1.20 g, $5 \mathrm{mmol})$ was dissolved in dry acetone $(40 \mathrm{~mL})$ and 2-chloro-N,N-dimethylethanamine (790 $\mathrm{mg}, 7.3 \mathrm{mmol}$ ) (prepared from the corresponding hydrochloride salt ${ }^{50}$ ), and $\mathrm{K}_{2} \mathrm{CO}_{3}(1.40 \mathrm{~g}, 10$ mmol) were added. The resulting mixture was maintained at reflux in an inert atmosphere for 18 hours. The reaction mixture was evaporated to dryness, the residue partitioned between $\mathrm{CH}_{2} \mathrm{Cl}_{2}(50 \mathrm{~mL})$ and $\mathrm{H}_{2} \mathrm{O}(50 \mathrm{~mL})$ and the aqueous layer extracted with $\mathrm{CH}_{2} \mathrm{Cl}_{2}(3 \times 20 \mathrm{~mL})$. The combined organic extracts were dried over $\mathrm{MgSO}_{4}$, filtered and evaporated to dryness. The crude product was purified by flash column chromatography $\left(\mathrm{SiO}_{2}\right)$, elution with $\mathrm{CH}_{2} \mathrm{Cl}_{2} / \mathrm{EtOH}$ (100/0 to 80/20), to afford $\mathbf{2 a}$ as oily product used without further purification $(1.13 \mathrm{~g}, 72 \%) .{ }^{1} \mathrm{H}$ NMR $\left(300 \mathrm{MHz}, \mathrm{CDCl}_{3}\right): \delta 7.82(\mathrm{~s}, 2 \mathrm{H}), 4.47$ (q, 4H), $4.24(\mathrm{t}, 2 \mathrm{H}), 2.80(\mathrm{t}$, $2 \mathrm{H}), 1.45(\mathrm{t}, 6 \mathrm{H})$. 
(4-(2-(Dimethylamino)ethoxy)pyridine-2,6-diyl)dimethanol 3a. Compound 2a (6.20 g, 20 mmol) was dissolved in absolute $\mathrm{EtOH}(170 \mathrm{~mL})$ and $\mathrm{NaBH}_{4}(5.10 \mathrm{~g}, 135 \mathrm{mmol})$ was added portion wise. The resulting mixture was stirred at room temperature under an inert atmosphere for 1 hour and then heated at reflux for $18 \mathrm{~h}$. The reaction was quenched by careful addition of $\mathrm{H}_{2} \mathrm{O}(10 \mathrm{~mL})$ and the solvent removed under reduced pressure. The residue was partitioned between $n \mathrm{BuOH}(180 \mathrm{~mL})$ and $\mathrm{H}_{2} \mathrm{O}(180 \mathrm{~mL})$ and the aqueous layer extracted with $n \mathrm{BuOH}$ $(2 \times 70 \mathrm{~mL})$. The combined organic layers were evaporated to dryness and then co-evaporated under reduced pressure with heptane $(4 \times 10 \mathrm{~mL})$ until a precipitate was formed, which corresponds to the desired product 3a (3.66 g, 80\%). M.p. $=135-137{ }^{\circ} \mathrm{C} .{ }^{1} \mathrm{H}$ NMR $(300 \mathrm{MHz}$, $\left.\mathrm{CDCl}_{3}\right): \delta 6.72(\mathrm{~s}, 2 \mathrm{H}), 4.68(\mathrm{~s}, 4 \mathrm{H}), 4.10(\mathrm{t}, 2 \mathrm{H}), 3.71$ (brs, 2H), $2.74(\mathrm{t}, 2 \mathrm{H}), 2.33(\mathrm{~s}, 6 \mathrm{H})$. Anal. Calcd for $\mathrm{C}_{11} \mathrm{H}_{18} \mathrm{~N}_{2} \mathrm{O}_{3}$ : C, 58.39; H, 8.02; N, 12.38. Found: C, 57.96; H, 7.98; N, 12.26.

4-(2-(Dimethylamino)ethoxy)pyridine-2,6-dicarbaldehyde 4a. To a hot solution of 3a (650 $\mathrm{mg}, 2.9 \mathrm{mmol})$ in 1,4-dioxane $(25 \mathrm{~mL})$ was added selenium dioxide $(750 \mathrm{mg}, 6.7 \mathrm{mmol})$ and the mixture was heated at reflux for 4 hours. The solvent was evaporated and the crude product was purified by flash column chromatography $\left(\mathrm{SiO}_{2}\right)$, elution with EtOAc/ $\mathrm{NEt}_{3}$ (100/0 to 95/5), to afford product $4 \mathbf{a}(480 \mathrm{mg}, 75 \%)$. The product was used without further purification. ${ }^{1} \mathrm{H} \mathrm{NMR}\left(300 \mathrm{MHz}, \mathrm{CDCl}_{3}\right): \delta 10.10(\mathrm{~s}, 2 \mathrm{H}), 7.67(\mathrm{~s}, 2 \mathrm{H}), 4.27(\mathrm{t}, 2 \mathrm{H}), 2.82(\mathrm{t}$, 2H), $2.37(\mathrm{~s}, 6 \mathrm{H})$.

2-((2,6-bis(Oxazol-5-yl)pyridin-4-yl)oxy)-N,N-dimethylethanamine 5a. A mixture of derivative 4a $(2.0 \mathrm{~g}, 9 \mathrm{mmol})$, TosMIC $(3.7 \mathrm{~g}, 19 \mathrm{mmol})$, and $\mathrm{K}_{2} \mathrm{CO}_{3}(5.3 \mathrm{~g}, 38 \mathrm{mmol})$ in 55 $\mathrm{mL}$ of absolute ethanol was heated at reflux for 2 hours. The reaction mixture was evaporated to dryness, the residue partitioned between $\mathrm{CH}_{2} \mathrm{Cl}_{2}(150 \mathrm{~mL})$ and $\mathrm{H}_{2} \mathrm{O}(150 \mathrm{~mL})$ and the aqueous layer extracted with $\mathrm{CH}_{2} \mathrm{Cl}_{2}(3 \times 50 \mathrm{~mL})$. The combined organic phases were dried over $\mathrm{MgSO}_{4}$, filtered and evaporated to dryness. The crude product was purified by flash column chromatography (neutral $\mathrm{Al}_{2} \mathrm{O}_{3}$ ) eluted with: $i$ ) cyclohexane/ $\mathrm{CH}_{2} \mathrm{Cl}_{2}$ (70/30 to 0/100), 
and ii) $\mathrm{CH}_{2} \mathrm{Cl}_{2} /$ EtOAc (95/5 to 85/15) to afford the desired product 5a (1.8 g, 66\%). M.p = 154-156 ${ }^{\circ} \mathrm{C} .{ }^{1} \mathrm{H}$ NMR $\left(300 \mathrm{MHz}, \mathrm{CDCl}_{3}\right): \delta 7.98(\mathrm{~s}, 2 \mathrm{H}), 7.76(\mathrm{~s}, 2 \mathrm{H}), 7.17(\mathrm{~s}, 2 \mathrm{H}), 4.24(\mathrm{t}$, $2 \mathrm{H}), 2.80(\mathrm{t}, 2 \mathrm{H}), 2.37(\mathrm{~s}, 6 \mathrm{H})$. Anal. Calcd for $\mathrm{C}_{15} \mathrm{H}_{16} \mathrm{~N}_{4} \mathrm{O}_{3}$ : C, 59.99; H, 5.37; N, 18.66. Found: C, 59.86; H, 5.20; N, 18.40.

\section{2-((2,6-bis(2-(6-(1,3-Dioxolan-2-yl)pyridin-2-yl)oxazol-5-yl)pyridin-4-yl)oxy)-N,N}

dimethylethanamine 7a. Compound 5a (620 mg, 2 mmol), 2-bromo-6-(1,3-dioxolan-2yl)pyridine $6(1.80 \mathrm{~g}, 7.8 \mathrm{mmol})^{24}$, palladium acetate $(235 \mathrm{mg}, 1 \mathrm{mmol}), \mathrm{Cs}_{2} \mathrm{CO}_{3}(3.0 \mathrm{~g}, 9.2$ mmol), copper (I) iodide (960 mg, $5 \mathrm{mmol}$ ), and $\mathrm{PCy}_{3} \cdot \mathrm{HBF}_{4}(253 \mathrm{mg}, 0.7 \mathrm{mmol})$ were suspended in 1,4-dioxane $(15 \mathrm{ml})$. The mixture was heated at reflux for 22 hours under argon. The solvent was removed under reduced pressure and the crude product was purified by flash column chromatography (neutral $\mathrm{Al}_{2} \mathrm{O}_{3}$ ), elution with EtOAc/EtOH (100/0 to 70/30), to afford product 7a (530 mg, 43\%). 7a was used without further purification. ${ }^{1} \mathrm{H}$ NMR (300 $\left.\mathrm{MHz}, \mathrm{CDCl}_{3}\right): \delta 8.23(\mathrm{~d}, 2 \mathrm{H}), 7.95-7.89(\mathrm{~m}, 4 \mathrm{H}), 7.68(\mathrm{~d}, 2 \mathrm{H}), 7.39(\mathrm{~s}, 2 \mathrm{H}), 6.02(\mathrm{~s}, 2 \mathrm{H}), 4.33$ (t, 2H), 4.27-4.10 (m, 8H), $2.84(\mathrm{t}, 2 \mathrm{H}), 2.41(\mathrm{~s}, 6 \mathrm{H})$.

\section{6,6'-(5,5'-(4-(2-(dimethylamino)ethoxy)pyridine-2,6-diyl)bis(oxazole-5,2-}

diyl))dipicolinaldehyde $8 \mathbf{a}$. A suspension of $7 \mathbf{a}(530 \mathrm{mg} ; 0.88 \mathrm{mmol})$ in $2 \mathrm{~N} \mathrm{HCl}(100 \mathrm{~mL})$ was stirred at room temperature for 7 days (until disappearance of signals belonging to dioxalane, monitored by NMR). The mixture was neutralized by addition of saturated $\mathrm{NaHCO}_{3}$ and extracted thoroughly with $\mathrm{CH}_{2} \mathrm{Cl}_{2}$. The organic phases were combined, dried over $\mathrm{MgSO}_{4}$, and the solvent evaporated to afford the desired product $8 \mathbf{a}(280 \mathrm{mg}, 62 \%)$ as white crystal. 8a was used without further purification. M.p. > $150{ }^{\circ} \mathrm{C} .{ }^{1} \mathrm{H}$ NMR $(300 \mathrm{MHz}$, $\left.\mathrm{CDCl}_{3}\right): \delta 10.27(\mathrm{~s}, 2 \mathrm{H}), 8.49-8.40(\mathrm{~m}, 2 \mathrm{H}), 8.12-8.05(\mathrm{~m}, 4 \mathrm{H}), 8.02(\mathrm{~s}, 2 \mathrm{H}), 7.24(\mathrm{~s}, 2 \mathrm{H})$, $4.35(\mathrm{t}, 2 \mathrm{H}), 2.86(\mathrm{t}, 2 \mathrm{H}), 2.42(\mathrm{~s}, 6 \mathrm{H})$. 


\section{2-((2,6-bis(2-(6-(Oxazol-5-yl)pyridin-2-yl)oxazol-5-yl)pyridin-4-yl)oxy)-N,N-}

dimethylethanamine 9a (TOxaPy-1). A mixture of 8a (280 mg, $0.55 \mathrm{mmol})$, TosMIC (340 $\mathrm{mg}, 1.7 \mathrm{mmol})$, and $\mathrm{K}_{2} \mathrm{CO}_{3}(420 \mathrm{mg}, 3 \mathrm{mmol})$ in absolute ethanol $(15 \mathrm{~mL})$ was heated at reflux for 2 hours. The reaction mixture was evaporated to dryness, the residue partitioned between $\mathrm{CH}_{2} \mathrm{Cl}_{2}(70 \mathrm{~mL})$ and $\mathrm{H}_{2} \mathrm{O}(50 \mathrm{~mL})$ and the aqueous layer was extracted with $\mathrm{CH}_{2} \mathrm{Cl}_{2}$ $(2 \times 30 \mathrm{~mL})$. The combined organic phases were dried over $\mathrm{MgSO}_{4}$, filtered and evaporated to dryness. The crude product was purified by flash column chromatography (neutral $\mathrm{Al}_{2} \mathrm{O}_{3}$ ), elution with $\mathrm{CH}_{2} \mathrm{Cl}_{2} / \mathrm{EtOH}$ (100/0 to $\left.97 / 3\right)$, to afford product 9a (130 mg, 40\%) as brown solid. M.p. > $155^{\circ} \mathrm{C} .{ }^{1} \mathrm{H}$ NMR $\left(300 \mathrm{MHz}, \mathrm{CDCl}_{3}\right): \delta 8.19$ (d, 2H), 8.04 (s, 2H), 8.00-7.94 (m, 6H), $7.79(\mathrm{~d}, 2 \mathrm{H}), 7.41(\mathrm{~s}, 2 \mathrm{H}), 4.35(\mathrm{t}, 2 \mathrm{H}), 2.88(\mathrm{t}, 2 \mathrm{H}), 2.43(\mathrm{~s}, 6 \mathrm{H})$. Anal. Calcd for $\mathrm{C}_{31} \mathrm{H}_{24} \mathrm{~N}_{8} \mathrm{O}_{5} \cdot \mathrm{H}_{2} \mathrm{O}: \mathrm{C}, 61.38 ; \mathrm{H}, 4.29 ; \mathrm{N}, 18.48$. Found: C, 61.83; H, 4.06; N, 18.62. HPLC injection: $T=4.94 \mathrm{~min}$. LRMS (ESI-MS): $\mathrm{m} / \mathrm{z}=589.3[\mathrm{M}+\mathrm{H}]^{+}$.

Formation of mesylate salt (TOxaPy-2). To the free base 9a $(20 \mathrm{mg})$ dissolved in NMP (0.6 $\mathrm{mL}$ ) were added $9 \mu \mathrm{L}$ of $\mathrm{CH}_{3} \mathrm{SO}_{3} \mathrm{H}$. After heating at $60^{\circ} \mathrm{C}$, the mixture was left 3 hours at room temperature and then ethyl ether $(1.5 \mathrm{~mL})$ was added. The precipitate was collected by filtration, washed with a small amount of ether and the resulting hygroscopic mesylate salt was dried under vacuum. ${ }^{1} \mathrm{H}$ NMR (300 MHz, DMSO-d $\left.{ }_{6}\right): \delta 9.60$ (brs, $\left.1 \mathrm{H}\right), 8.65(\mathrm{~s}, 2 \mathrm{H})$, 8.25-8.16 (m, 6H), 8.02-7.96 (m, 4H), $7.55(\mathrm{~s}, 2 \mathrm{H}), 4.73(\mathrm{t}, 2 \mathrm{H}), 3.70-3.64(\mathrm{~m}, 2 \mathrm{H}), 2.96$ \& $2.95(2 \mathrm{x} \mathrm{s}, 6 \mathrm{H}), 2.32$ (s, 3H). HPLC injection: $T=4.98 \mathrm{~min}$. LRMS (ESI-MS): $\mathrm{m} / \mathrm{z}=589.3$ $[\mathrm{M}+\mathrm{H}]^{+}$.

Formation of maleate salt (TOxaPy-3). To the free base 9a $(62 \mathrm{mg})$ dissolved in THF + EtOH $(7 \mathrm{~mL}+2 \mathrm{~mL})$ was added maleic acid $(19 \mathrm{mg})$ in acetone $(2 \mathrm{~mL})$. After heating at $50^{\circ} \mathrm{C}$, the mixture was left 3 hours at room temperature. The mixture was evaporated to dryness and diethyl ether $(5 \mathrm{~mL})$ was added. The precipitate was collected by filtration, 
washed with ether $(2 \mathrm{~mL})$ and the resulting hygroscopic maleate salt was dried under vacuum (74 mg). HPLC injection: $T=4.95 \mathrm{~min} . \mathrm{LRMS}(\mathrm{ESI}-\mathrm{MS}): \mathrm{m} / \mathrm{z}=589.3[\mathrm{M}+\mathrm{H}]^{+}$.

Diethyl 4-(2-(piperidin-1-yl)ethoxy)pyridine-2,6-dicarboxylate 2b. Compound 1 (7.70 g, $32 \mathrm{mmol})$ was dissolved in dry acetone $(100 \mathrm{~mL})$ and 1-(2-chloroethyl)piperidine $(6.10 \mathrm{~g}, 41$ mmol), and $\mathrm{K}_{2} \mathrm{CO}_{3}(9.4 \mathrm{~g}, 68 \mathrm{mmol})$ were added. ${ }^{51}$ The resulting mixture was maintained at reflux in an inert atmosphere for 18 hours. The reaction mixture was evaporated to dryness, the residue partitioned between $\mathrm{CH}_{2} \mathrm{Cl}_{2}(100 \mathrm{~mL})$ and $\mathrm{H}_{2} \mathrm{O}(70 \mathrm{~mL})$ and the aqueous layer extracted with $\mathrm{CH}_{2} \mathrm{Cl}_{2}(3 \times 50 \mathrm{~mL})$. The combined organic layers were dried over $\mathrm{MgSO}_{4}$, filtered and evaporated to dryness. The crude product was purified by flash column chromatography $\left(\mathrm{SiO}_{2}\right)$, elution with $\mathrm{CH}_{2} \mathrm{Cl}_{2} / \mathrm{EtOH}$ (100/0 to 80/20), to afford $2 \mathbf{b}(9.20 \mathrm{~g}$, $81 \%)$ as brown oil. $\mathbf{2 b}$ was used without further purification. ${ }^{1} \mathrm{H} \mathrm{NMR}\left(300 \mathrm{MHz}, \mathrm{CDCl}_{3}\right): \delta$ $7.80(\mathrm{~s}, 2 \mathrm{H}), 4.47(\mathrm{q}, 4 \mathrm{H}), 4.26(\mathrm{t}, 2 \mathrm{H}), 2.81(\mathrm{t}, 2 \mathrm{H}), 2.54-2.47(\mathrm{~m}, 4 \mathrm{H}), 1.65-1.55(\mathrm{~m}, 4 \mathrm{H})$, $1.50-1.42(\mathrm{~m}, 8 \mathrm{H})$.

(4-(2-(piperidin-1-yl)ethoxy)pyridine-2,6-diyl)dimethanol 3b. Compound 2 b $(9.0$ g, 26 mmol) was dissolved in absolute EtOH $(200 \mathrm{~mL}) . \mathrm{NaBH}_{4}(6.50 \mathrm{~g}, 170 \mathrm{mmol})$ was added portion wise and the resulting mixture stirred at room temperature under an inert atmosphere for 1 hour and then heated at reflux for 18 hours. The reaction was quenched by careful addition of $\mathrm{H}_{2} \mathrm{O}(10 \mathrm{~mL})$ and evaporated to dryness. The residue was partitioned between $n \mathrm{BuOH}(100 \mathrm{~mL})$ and $\mathrm{H}_{2} \mathrm{O}(150 \mathrm{~mL})$ and the aqueous layer was extracted with $n \mathrm{BuOH}(2 \times$ $50 \mathrm{~mL}$ ). The combined organic layers were evaporated to dryness and then co-evaporated under reduced pressure with heptane $(4 \times 10 \mathrm{~mL})$. An off-white precipitate was formed corresponding to the desired compound $3 \mathbf{b}\left(6.1\right.$ g, 89\%). M.p. $=135-137{ }^{\circ} \mathrm{C} .{ }^{1} \mathrm{H}$ NMR $(300$ $\left.\mathrm{MHz}, \mathrm{CDCl}_{3}\right): \delta 6.70(\mathrm{~s}, 2 \mathrm{H}), 4.65(\mathrm{~s}, 4 \mathrm{H}), 4.11(\mathrm{t}, 2 \mathrm{H}), 2.75(\mathrm{t}, 2 \mathrm{H}), 2.50(\mathrm{t}, 4 \mathrm{H}), 1.65-1.55$ (m, 4H), 1.50-1.40 (m, 2H). Anal. Calcd for $\mathrm{C}_{14} \mathrm{H}_{22} \mathrm{~N}_{2} \mathrm{O}_{3} \cdot 0.25 \mathrm{H}_{2} \mathrm{O}: \mathrm{C}, 62.10 ; \mathrm{H}, 8.31 ; \mathrm{N}$, 10.35. Found: C, 62.07; H, 8.38; N, 10.25. 
4-(2-(Piperidin-1-yl)ethoxy)pyridine-2,6-dicarbaldehyde 4b. To a hot solution of compound $3 \mathbf{b}$ (1.94 g, $7.3 \mathrm{mmol})$ in 1,4-dioxane $(75 \mathrm{~mL})$ was added selenium dioxide $(2.4 \mathrm{~g}$, $22 \mathrm{mmol}$ ) and the mixture was heated at reflux for 5 hours. The solvent was evaporated and the crude product was purified by flash column chromatography $\left(\mathrm{SiO}_{2}\right)$, elution with EtOAc/NEt 3 (100/0 to 95/5), to afford desired product $\mathbf{4 b}(1.05 \mathrm{~g}, 55 \%)$ as dark beige crystal. M.p. $=136-138{ }^{\circ} \mathrm{C} .{ }^{1} \mathrm{H}$ NMR $\left(300 \mathrm{MHz}, \mathrm{CDCl}_{3}\right): \delta 10.11(\mathrm{~s}, 2 \mathrm{H}), 7.66(\mathrm{~s}, 2 \mathrm{H}), 4.27(\mathrm{t}, 2 \mathrm{H})$, $2.82(\mathrm{t}, 2 \mathrm{H}), 2.51(\mathrm{t}, 4 \mathrm{H}), 1.66-1.55(\mathrm{~m}, 4 \mathrm{H}), 1.50-1.41(\mathrm{~m}, 2 \mathrm{H})$. Anal. Calcd for $\mathrm{C}_{14} \mathrm{H}_{18} \mathrm{~N}_{2} \mathrm{O}_{3}$ : C, 64.10; H, 6.92; N, 10.68. Found: C, 63.96; H, 6.99; N, 10.87.

5,5'-(4-(2-(Piperidin-1-yl)ethoxy)pyridine-2,6-diyl)bis(oxazole) 5b. A mixture of derivative 4b (1.0 g, $3.8 \mathrm{mmol})$, TosMIC (1.6 g, $8.2 \mathrm{mmol})$, and $\mathrm{K}_{2} \mathrm{CO}_{3}(2.7 \mathrm{~g}, 20 \mathrm{mmol})$ in $30 \mathrm{~mL}$ of absolute ethanol was heated at reflux for 2 hours. The reaction mixture was evaporated to dryness, the residue partitioned between $\mathrm{CH}_{2} \mathrm{Cl}_{2}(150 \mathrm{~mL})$ and $\mathrm{H}_{2} \mathrm{O}(150 \mathrm{~mL})$ and the aqueous layer extracted with $\mathrm{CH}_{2} \mathrm{Cl}_{2}(3 \times 50 \mathrm{~mL})$. The combined organic extracts were dried over $\mathrm{MgSO}_{4}$, filtered and evaporated to dryness. The crude product was purified by flash column chromatography (neutral $\mathrm{Al}_{2} \mathrm{O}_{3}$ ), elution with cyclohexane/EtOAc (70/30 to 0/100), to afford the desired product $\mathbf{5 b}(810 \mathrm{mg}, 62 \%)$. 5b was used without further purification. M.p. $=122-125{ }^{\circ} \mathrm{C} .{ }^{1} \mathrm{H}$ NMR $\left(300 \mathrm{MHz}, \mathrm{CDCl}_{3}\right): \delta 7.98(\mathrm{~s}, 2 \mathrm{H}), 7.76(\mathrm{~s}, 2 \mathrm{H}), 7.16(\mathrm{~s}, 2 \mathrm{H}), 4.27(\mathrm{t}$, $2 \mathrm{H}), 2.83(\mathrm{t}, 2 \mathrm{H}), 2.53(\mathrm{t}, 4 \mathrm{H}), 1.68-1.58(\mathrm{~m}, 4 \mathrm{H}), 1.51-1.44(\mathrm{~m}, 2 \mathrm{H})$.

\section{5,5'-(4-(2-(Piperidin-1-yl)ethoxy)pyridine-2,6-diyl)bis(2-(6-(1,3-dioxolan-2-yl)pyridin-2-}

yl)oxazole) 7b. A mixture of intermediate 5b (660 mg; $1.94 \mathrm{mmol})$, 2-bromo-6-(1,3dioxolan-2-yl)pyridine $6(1.66 \mathrm{~g}, 7.2 \mathrm{mmol})^{24}$, palladium acetate $(220 \mathrm{mg}, 1 \mathrm{mmol}), \mathrm{Cs}_{2} \mathrm{CO}_{3}$ (2.7 g, $8.3 \mathrm{mmol})$, copper (I) iodide $(950 \mathrm{mg}, 5 \mathrm{mmol})$, and $\mathrm{PCy}_{3} \cdot \mathrm{HBF}_{4}(250 \mathrm{mg}, 0.7 \mathrm{mmol})$ was suspended in 1,4-dioxane $(23 \mathrm{ml})$. The mixture was heated under reflux for 18 hours under inert atmosphere. The solvent was evaporated under reduced pressure and the crude product was purified by flash column chromatography $\left(\mathrm{SiO}_{2}\right)$, elution in EtOAc/EtOH 3\% 
$\mathrm{NEt}_{3}$ (100/0 to 50/50), to afford compound $7 \mathbf{b}(440 \mathrm{mg}, 35 \%)$ as a pale yellow crystal. M.p. $=$ 174-176 ${ }^{\circ} \mathrm{C} .{ }^{1} \mathrm{H}$ NMR $\left(300 \mathrm{MHz}, \mathrm{CDCl}_{3}\right): \delta 8.23(\mathrm{~d}, 2 \mathrm{H}), 7.97-7.88(\mathrm{~m}, 4 \mathrm{H}), 7.68(\mathrm{~d}, 2 \mathrm{H})$, $7.37(\mathrm{~s}, 2 \mathrm{H}), 6.03(\mathrm{~s}, 2 \mathrm{H}), 4.35(\mathrm{t}, 2 \mathrm{H}), 4.27-4.10(\mathrm{~m}, 8 \mathrm{H}), 2.88(\mathrm{t}, 2 \mathrm{H}), 2.61-2.52(\mathrm{~m}, 4 \mathrm{H})$, 1.70-1.63 (m, 4H), 151-1.45 (m, $2 \mathrm{H})$. Anal. Calcd for $\mathrm{C}_{34} \mathrm{H}_{34} \mathrm{~N}_{6} \mathrm{O}_{7} \cdot 2 \mathrm{H}_{2} \mathrm{O}: \mathrm{C}, 60.53 ; \mathrm{H}, 5.63$; N, 12.46. Found: C, 60.68; H, 5.67; N, 11.95.

\section{6,6'-(5,5'-(4-(2-(piperidin-1-yl)ethoxy)pyridine-2,6-diyl)bis(oxazole-5,2-}

diyl))dipicolinaldehyde $8 \mathbf{b}$. A suspension of compound $\mathbf{7 b}(420 \mathrm{mg}, 0.66 \mathrm{mmol})$ in $2 \mathrm{~N} \mathrm{HCl}$ $(70 \mathrm{~mL})$ was stirred at room temperature for 12 days (until disappearance of signals belonging to dioxolane, monitored by NMR). The mixture was neutralized by addition of saturated $\mathrm{NaHCO}_{3}$ and extracted thoroughly with $\mathrm{CH}_{2} \mathrm{Cl}_{2}$. The organic phases were combined, dried over $\mathrm{MgSO}_{4}$, and evaporated to afford the crude product $\mathbf{8 b}$ (120 mg, 33\%), which was used in the next step without further purification. ${ }^{1} \mathrm{H}$ NMR $\left(300 \mathrm{MHz}, \mathrm{CDCl}_{3}\right): \delta 10.26(\mathrm{~s}, 2 \mathrm{H})$, 8.50-8.41 (m, 2H), 8.10-8.04 (m, 4H), $8.00(\mathrm{~s}, 2 \mathrm{H}), 7.38(\mathrm{~s}, 2 \mathrm{H}), 4.37(\mathrm{t}, 2 \mathrm{H}), 2.89(\mathrm{t}, 2 \mathrm{H})$, 2.62-2.53 (m, 4H), 1.67-1.62 (m, 4H), 1.47-1.43 (m, 2H).

\section{5,5'-(4-(2-(Piperidin-1-yl)ethoxy)pyridine-2,6-diyl)bis(2-(6-(oxazol-5-yl)pyridin-2-}

yl)oxazole) 9b (TOxaPy-4). A mixture of compound $8 \mathbf{b}$ (120 mg, $0.22 \mathrm{mmol})$, TosMIC (130 $\mathrm{mg}, 0.66 \mathrm{mmol})$, and $\mathrm{K}_{2} \mathrm{CO}_{3}(155 \mathrm{mg}, 1.1 \mathrm{mmol})$ in $10 \mathrm{~mL}$ of absolute ethanol was heated at reflux for 2 hours. The reaction mixture was evaporated to dryness, the residue partitioned between $\mathrm{CH}_{2} \mathrm{Cl}_{2}(50 \mathrm{~mL})$ and $\mathrm{H}_{2} \mathrm{O}(40 \mathrm{~mL})$ and the aqueous layer extracted thoroughly with $\mathrm{CH}_{2} \mathrm{Cl}_{2}$. The combined organic phases were dried over $\mathrm{MgSO}_{4}$ and evaporated to dryness. The crude product was purified by flash column chromatography (neutral $\mathrm{Al}_{2} \mathrm{O}_{3}$ ), elution with $\mathrm{CH}_{2} \mathrm{Cl}_{2} / \mathrm{EtOH}$ (100/0 to $\left.95 / 5\right)$ to afford desired product $9 \mathbf{b}(30 \mathrm{mg}, 21 \%)$ as beige crystal. M.p. $=257-259{ }^{\circ} \mathrm{C} .{ }^{1} \mathrm{H}$ NMR $\left(300 \mathrm{MHz}, \mathrm{CDCl}_{3}\right): \delta 8.20(\mathrm{~d}, 2 \mathrm{H}), 8.04(\mathrm{~s}, 2 \mathrm{H}), 8.00-7.94(\mathrm{~m}$, $6 \mathrm{H}), 7.79(\mathrm{~d}, 2 \mathrm{H}), 7.40(\mathrm{~s}, 2 \mathrm{H}), 4.38(\mathrm{t}, 2 \mathrm{H}), 2.90(\mathrm{t}, 2 \mathrm{H}), 2.60-2.57(\mathrm{~m}, 4 \mathrm{H}), 1.69-1.66(\mathrm{~m}$, 4H), 1.52-1.46 (m, 2H). Anal. Calcd for $\mathrm{C}_{34} \mathrm{H}_{28} \mathrm{~N}_{8} \mathrm{O}_{5} \cdot \mathrm{H}_{2} \mathrm{O}: \mathrm{C}, 63.45 ; \mathrm{H}, 4.66 ; \mathrm{N}, 17.42$. 
Found: C, 63.98; H, 4.68; N, 17.88. HPLC injection: $T=5.12 \mathrm{~min}$. LRMS (ESI-MS): m/z= $629.3[\mathrm{M}+\mathrm{H}]^{+}$.

Formation of mesylate salt (TOxaPy-5). To the free base $\mathbf{9 b}(10 \mathrm{mg})$ dissolved in NMP (0.3 $\mathrm{mL}$ ) were added $6 \mu \mathrm{L}$ of $\mathrm{CH}_{3} \mathrm{SO}_{3} \mathrm{H}$. After heating at $60^{\circ} \mathrm{C}$, the mixture was left for 3 hours at room temperature and ethyl ether $(1.5 \mathrm{~mL})$ was added. The precipitate was collected by filtration, washed with a small amount of ethyl ether and the resulting hygroscopic mesylate salt was dried under vacuum (10 mg). ${ }^{1} \mathrm{H}$ NMR (300 MHz, DMSO-d 6 ): $\delta 9.32$ (br s, $\left.1 \mathrm{H}\right), 8.65$ (s, 2H), 8.28-8.14 (m, 6H), 8.02-7.96 (m, 4H), $7.55(\mathrm{~s}, 2 \mathrm{H}), 4.74(\mathrm{t}, 2 \mathrm{H}), 3.70-3.60(\mathrm{~m}, 4 \mathrm{H})$, 3.14-3.04 (m, 2H), $2.31(\mathrm{~s}, 3 \mathrm{H}), 1.90-1.65(\mathrm{~m}, 6 \mathrm{H})$. HPLC injection: $T=5.12 \mathrm{~min}$. LRMS (ESI-MS): $\mathrm{m} / \mathrm{z}=629.3[\mathrm{M}+\mathrm{H}]^{+}$.

\subsubsection{Synthesis of iso-BOxaPy and its (pyridin-4-yl)oxy)-N,N-dimethylethanamine} derivative. The synthesis of iso-BOxaPy and its derivative was performed following a multistep synthetic pathway described in the subsequent protocols.

Synthesis of 2,6-bis(5-(Pyridin-2-yl)oxazol-2-yl)pyridine 12 (iso-BOxaPy). A mixture of 5(pyridin-2-yl)oxazole $\mathbf{1 0}(1.0 \mathrm{~g}, 6.8 \mathrm{mmol})$, obtained as reported in literature ${ }^{37}, 2,6-$ dibromopyridine 11 (540 mg, $2.3 \mathrm{mmol}$ ), palladium diacetate (235 mg, $1.0 \mathrm{mmol}$ ), $\mathrm{PCy}_{3} \cdot \mathrm{HBF}_{4}$ (240 mg, $0.6 \mathrm{mmol}$ ), copper (I) iodide (900 mg, $\left.4.7 \mathrm{mmol}\right), \mathrm{Cs}_{2} \mathrm{CO}_{3}(3.0 \mathrm{~g}, 9.2$ mmol) in $15 \mathrm{~mL}$ of anhydrous 1,4-dioxane was heated under reflux for 22 hours. The crude product was purified by flash column chromatography $\left(\mathrm{SiO}_{2}\right)$, elution with EtOAc/EtOH (100/0 to 80/20), to afford compound 12 as a pale yellow solid $(700 \mathrm{mg}, 83 \%)$. M.p. $=230$ ${ }^{\circ} \mathrm{C} .{ }^{1} \mathrm{H}$ NMR $\left(300 \mathrm{MHz}, \mathrm{CDCl}_{3}\right): \delta$ 8.70-8.68 (m, 2H), $8.33(\mathrm{~d}, 2 \mathrm{H}), 8.06-7.95(\mathrm{~m}, 5 \mathrm{H}), 7.87-$ $7.81(\mathrm{~m}, 2 \mathrm{H})$, 7.32-7.26 (m, 2H). Anal. Calcd for $\mathrm{C}_{21} \mathrm{H}_{13} \mathrm{~N}_{5} \mathrm{O}_{2}{ }^{\cdot 1.33} \mathrm{H}_{2} \mathrm{O}: \mathrm{C}, 64.46 ; \mathrm{H}, 4.00 ; \mathrm{N}$, 17.90. Found: C, 64.35; H, 3.87; N, 17.47. HPLC injection: $T=5.60 \mathrm{~min}$. LRMS (ESI-MS): $\mathrm{m} / \mathrm{z}=368.2[\mathrm{M}+\mathrm{H}]^{+}$. 
Synthesis of 2-((2,6-bis(5-(Pyridin-2-yl)oxazol-2-yl)pyridin-4-yl)oxy)-N,Ndimethylethanami -ne 15 (iso-BOxaPy-1).

2-((2,6-dibromopyridin-4-yl)oxy)-N,N-dimethylethanamine 14. To $\mathrm{NaH}$ (60\%, 270 mg, $6.7 \mathrm{mmol})$ was added THF $(20 \mathrm{~mL})$ at $0{ }^{\circ} \mathrm{C}$. To the suspension, 2-(dimethylamino)ethanol (545 $\mathrm{mg}, 0.6 \mathrm{~mL}, 6.1 \mathrm{mmol}$ ) was added in three portions and the obtained suspension was stirred at $0{ }^{\circ} \mathrm{C}$ for $10 \mathrm{~min}$. 2,6-dibromo-4-nitropyridine 13 (1.40 g, $\left.5 \mathrm{mmol}\right)$ was added and the reaction mixture was stirred at room temperature for 3 hours. $15 \%$ ammonium chloride solution $(50 \mathrm{~mL})$ was added and the mixture was extracted with $\mathrm{CH}_{2} \mathrm{Cl}_{2}$. The organic layer was dried over $\mathrm{MgSO}_{4}$ and the solvent removed under reduced pressure giving the desired product 14 (1.54 g, 94\%) as brown amorphous solid. 14 was used without further purification. ${ }^{1} \mathrm{H}$ NMR $\left(300 \mathrm{MHz}, \mathrm{CDCl}_{3}\right): \delta 7.01(\mathrm{~s}, 2 \mathrm{H}), 4.10(\mathrm{t}, 2 \mathrm{H}), 2.73(\mathrm{t}, 2 \mathrm{H}), 2.33(\mathrm{~s}, 6 \mathrm{H})$. Anal. Calcd for $\mathrm{C}_{9} \mathrm{H}_{12} \mathrm{Br}_{2} \mathrm{~N}_{2} \mathrm{O}$ : C, 33.36; H, 3.73; N, 8.65. Found: C, 33.80; H, 3.85; N, 8.70.

2,6-bis(5-(Pyridin-2-yl)oxazol-2-yl)pyridine 15 iso-BOxaPy-1. A mixture of 10 (490 mg, $3.4 \mathrm{mmol})^{37}$, compound $14(357 \mathrm{mg}, 1.1 \mathrm{mmol})$, palladium diacetate $(148 \mathrm{mg}, 0.66 \mathrm{mmol})$, $\mathrm{PCy}_{3} \cdot \mathrm{HBF}_{4}(118 \mathrm{mg}, 0.32 \mathrm{mmol})$, copper (I) iodide (470 mg, $\left.2.5 \mathrm{mmol}\right)$, and $\mathrm{Cs}_{2} \mathrm{CO}_{3}(1.6 \mathrm{~g}$, $4.9 \mathrm{mmol}$ ) in $7 \mathrm{~mL}$ of anhydrous 1,4-dioxane was heated under reflux for 18 hours. The crude product was purified by flash column chromatography $\left(\mathrm{SiO}_{2}\right)$, elution with EtOAc/EtOH 3\% $\mathrm{NEt}_{3}(100 / 0$ to $60 / 40)$ to afford compound 14 as a pale yellow solid (300 mg, 60\%). M.p. = 180-184 ${ }^{\circ} \mathrm{C} .{ }^{1} \mathrm{H}$ NMR (300 MHz, $\left.\mathrm{CDCl}_{3}\right): \delta$ 8.69-8.68 (m, 2H), 8.02-7.99 (m, 2H), 7.92 (s, 2H), $7.88(\mathrm{~s}, 2 \mathrm{H}), 7.87-7.81(\mathrm{~m}, 2 \mathrm{H}), 7.31-7.27(\mathrm{~m}, 2 \mathrm{H}), 4.33(\mathrm{t}, 2 \mathrm{H}), 2.84(\mathrm{t}, 2 \mathrm{H}), 2.39(\mathrm{~s}$, 6H). Anal. Calcd for $\mathrm{C}_{25} \mathrm{H}_{22} \mathrm{~N}_{6} \mathrm{O}_{3} 3 \mathrm{H}_{2} \mathrm{O}$ : C, 59.05; H, 5.50; N, 16.53. Found: C, 59.15; H, 5.50; N, 16.42. HPLC injection: $T=4.61 \mathrm{~min} . \mathrm{LRMS}(\mathrm{ESI}-\mathrm{MS}): \mathrm{m} / \mathrm{z}=455.3[\mathrm{M}+\mathrm{H}]^{+}$.

Formation of mesylate salt iso-BOxaPy-2. To the free base $15(63 \mathrm{mg})$ dissolved in NMP (2 $\mathrm{mL}$ ) were added $28 \mu \mathrm{L}$ of $\mathrm{CH}_{3} \mathrm{SO}_{3} \mathrm{H}$. After heating at $60^{\circ} \mathrm{C}$, the mixture was left for 3 hours 
at room temperature and ethyl ether $(6 \mathrm{~mL})$ was added. The precipitate was collected by filtration, washed with ethyl ether $(2 \times 3 \mathrm{~mL})$ and the resulting mesylate salt was dried under vacuum. ${ }^{1} \mathrm{H}$ NMR (300 MHz, DMSO-d 6 ): $\delta 9.67$ (brs, 1H), $8.74(\mathrm{~d}, 2 \mathrm{H}), 8.14(\mathrm{~s}, 2 \mathrm{H}), 8.10$ $7.98(\mathrm{~m}, 4 \mathrm{H}), 7.94(\mathrm{~s}, 2 \mathrm{H}), 7.54-7.46(\mathrm{~m}, 2 \mathrm{H}), 7.42(\mathrm{t}, 2 \mathrm{H}), 3.70(\mathrm{~m}, 2 \mathrm{H}), 2.95 \& 2.93(2 \mathrm{x} \mathrm{s}$, 6H), 2.40 (s, 3H). HPLC injection: $T=4.63 \mathrm{~min}$. LRMS (ESI-MS): $\mathrm{m} / \mathrm{z}=455.3[\mathrm{M}+\mathrm{H}]^{+}$.

4.1.3 Synthesis of iso-TOxaPy and iso-TOxaPy derivatives. The synthesis of iso-TOxaPy derivatives was performed following a multistep synthetic pathway described in the subsequent protocols.

Synthesis of 2,6-bis(5-(6-(Oxazol-5-yl)pyridin-2-yl)oxazol-2-yl)pyridine 17 (iso-TOxaPy).

Pathway a. A mixture of compound $\mathbf{1 6}(210 \mathrm{mg}, 1 \mathrm{mmol})^{24}$, 2,6-dibromopyridine 11 (240 $\mathrm{mg}, 1 \mathrm{mmol}$ ), palladium diacetate $(40 \mathrm{mg}, 0.17 \mathrm{mmol}), \mathrm{PCy}_{3} \cdot \mathrm{HBF}_{4}(60 \mathrm{mg}, 0.25 \mathrm{mmol})$, copper (I) iodide $(210 \mathrm{mg}, 1.1 \mathrm{mmol})$, and $\mathrm{Cs}_{2} \mathrm{CO}_{3}(640 \mathrm{mg}, 2 \mathrm{mmol})$ in $7 \mathrm{~mL}$ of anhydrous 1,4-dioxane was heated at reflux for 22 hours. The crude product was purified by flash column chromatography $\left(\mathrm{SiO}_{2}\right)$, elution with $\mathrm{CH}_{2} \mathrm{Cl}_{2} / \mathrm{EtOH}$ (100/0 to 90/10), to afford titled compound 17 as a pale yellow solid (iso-TOxaPy, $20 \mathrm{mg}, 4 \%$ ). M.p. $>260{ }^{\circ} \mathrm{C} .{ }^{1} \mathrm{H}$ NMR $(300$ $\left.\mathrm{MHz}, \mathrm{CDCl}_{3}\right): \delta 8.37(\mathrm{~d}, 2 \mathrm{H}), 8.07(\mathrm{~d}, 1 \mathrm{H}), 8.03(\mathrm{~s}, 2 \mathrm{H}), 8.00-7.97(\mathrm{~m}, 6 \mathrm{H}), 7.91(\mathrm{~s}, 2 \mathrm{H})$, 7.70-7.67 (m, 2H). HPLC injection: $T=6.37 \mathrm{~min}$. LRMS (ESI-MS): $\mathrm{m} / \mathrm{z}=502.2[\mathrm{M}+\mathrm{H}]^{+}$. HRMS (ESI-MS): 502.1250 (calculated: $502.1264 \mathrm{C}_{27} \mathrm{H}_{16} \mathrm{~N}_{7} \mathrm{O}_{4}{ }^{+}$).

\section{Pathway b. Multistep synthetic pathway}

6-(Oxazol-5-yl)picolinaldehyde 19. A mixture of pyridine-2,6-dicarbaldehyde 18 (10.8 g, 80 mmol), TosMIC (7.8 g, $40 \mathrm{mmol})$, and $\mathrm{K}_{2} \mathrm{CO}_{3}(6.5 \mathrm{~g}, 47 \mathrm{mmol})$ in $150 \mathrm{~mL}$ of methanol was stirred at $0^{\circ} \mathrm{C}$ for $30 \mathrm{~min}$ then at room temperature for 2 hours. The reaction mixture was evaporated to dryness, the residue partitioned between $\mathrm{CH}_{2} \mathrm{Cl}_{2}(200 \mathrm{~mL})$ and $\mathrm{H}_{2} \mathrm{O}(200 \mathrm{~mL})$ and the aqueous layer was extracted with $\mathrm{CH}_{2} \mathrm{Cl}_{2}(3 \times 50 \mathrm{~mL})$. The combined organic extracts 
were dried over $\mathrm{MgSO}_{4}$, filtered and evaporated to dryness. The crude product was purified by flash column chromatography $\left(\mathrm{SiO}_{2}\right)$, elution with $\mathrm{CH}_{2} \mathrm{Cl}_{2} / \mathrm{EtOAc}(100 / 0$ to $0 / 100)$, to afford product $19(2.8 \mathrm{~g}, 34 \%)$ as pale yellow powder. M.p. $=148-150{ }^{\circ} \mathrm{C} .{ }^{52}{ }^{1} \mathrm{H}$ NMR $(300$ $\left.\mathrm{MHz}, \mathrm{CDCl}_{3}\right): \delta 7.98(\mathrm{~s}, 2 \mathrm{H}), 7.76(\mathrm{~s}, 2 \mathrm{H}), 7.16(\mathrm{~s}, 2 \mathrm{H}), 4.27(\mathrm{t}, 2 \mathrm{H}), 2.83(\mathrm{t}, 2 \mathrm{H}), 2.53(\mathrm{t}$, $4 \mathrm{H}), 1.68-1.58(\mathrm{~m}, 4 \mathrm{H}), 1.51-1.44(\mathrm{~m}, 2 \mathrm{H})$.

5-(6-(1,3-Dioxolan-2-yl)pyridin-2-yl)oxazole 20. Compound 20 was obtained following a method previously published. ${ }^{40}$ A mixture of compound 19 (1.64 g, $\left.9.4 \mathrm{mmol}\right), p$ toluenesulfonic acid monohydrate $(120 \mathrm{mg}, 0.6 \mathrm{mmol})$ and ethylene glycol (1.50 g, $24 \mathrm{mmol})$ in cyclohexane $(100 \mathrm{~mL})$ was heated under reflux for 2 hours. The reaction mixture was evaporated to dryness, the residue partitioned between $\mathrm{CH}_{2} \mathrm{Cl}_{2}(50 \mathrm{~mL})$ and $\mathrm{H}_{2} \mathrm{O}(70 \mathrm{~mL})$ and the aqueous layer was extracted with $\mathrm{CH}_{2} \mathrm{Cl}_{2}(2 \times 30 \mathrm{~mL})$. The combined organic extracts were dried over $\mathrm{MgSO}_{4}$, filtered and evaporated to dryness. The crude product was purified by flash column chromatography $\left(\mathrm{SiO}_{2}\right)$, elution with $\mathrm{CH}_{2} \mathrm{Cl}_{2} / \mathrm{EtOAc}(100 / 0$ to $75 / 25)$, to afford compound $\mathbf{2 0}(1.31 \mathrm{~g}, 63 \%)$ as a colorless oil.

2,6-bis(5-(6-(1,3-Dioxolan-2-yl)pyridin-2-yl)oxazol-2-yl)pyridine 21. A mixture of dioxolan-2-ylpyridine 20 (1.31 g, 6 mmol), 2,6-dibromopyridine 11 (480 mg, 2 mmol), palladium acetate $(230 \mathrm{mg}, 1 \mathrm{mmol}), \mathrm{Cs}_{2} \mathrm{CO}_{3}(2.7 \mathrm{~g}, 8.3 \mathrm{mmol})$, copper (I) iodide (900 mg, $4.7 \mathrm{mmol})$ and $\mathrm{PCy}_{3} \cdot \mathrm{HBF}_{4}(230 \mathrm{mg}, 0.6 \mathrm{mmol})$ was suspended in 1,4-dioxane $(15 \mathrm{ml})$. The mixture was heated under reflux for 16 hours under argon. The solvent was evaporated under reduced pressure and the crude product was purified by two flash column chromatographies: i) (neutral $\mathrm{Al}_{2} \mathrm{O}_{3}$ ), elution with $\mathrm{CH}_{2} \mathrm{Cl}_{2} / \mathrm{EtOAc}(100 / 0$ to $80 / 20)$ and $\left.\mathrm{ii}\right)\left(\mathrm{SiO}_{2}\right)$, elution with $\mathrm{CH}_{2} \mathrm{Cl}_{2} / \mathrm{EtOH}$ (100/0 to 97/3), to afford product 21 (640 mg, 61\%) as fair beige microcrystal. M.p.>260 ${ }^{\circ} \mathrm{C} .{ }^{1} \mathrm{H}$ NMR $\left(300 \mathrm{MHz}, \mathrm{CDCl}_{3}\right): \delta 8.32(\mathrm{~d}, 2 \mathrm{H}), 8.06-7.98(\mathrm{~m}, 5 \mathrm{H})$, 7.92-7.85 (m, 2H), $7.53(\mathrm{~m}, 2 \mathrm{H}), 5.92(\mathrm{~s}, 2 \mathrm{H}), 4.25-4.12(\mathrm{~m}, 8 \mathrm{H})$. 
6,6'-(2,2'-(Pyridine-2,6-diyl)bis(oxazole-5,2-diyl))dipicolinaldehyde 22. A suspension of finely pulverized $21(150 \mathrm{mg}, 2.9 \mathrm{mmol})$ in $2 \mathrm{~N} \mathrm{HCl}(40 \mathrm{~mL})$ was stirred at room temperature for 1 hour and then heated under reflux for 2 hours (until disappearance of signals belonging to dioxalane, monitored by NMR). The mixture was neutralized by addition of saturated $\mathrm{NaHCO}_{3}$ and stirred at room temperature for 2 hours. The precipitate was filtered, wash with water and dried (at $100^{\circ} \mathrm{C}$ ) to afford the desired product $22(105 \mathrm{mg}, 84 \%) .22$ was used without further purification. ${ }^{1} \mathrm{H}$ NMR $\left(300 \mathrm{MHz} \mathrm{CDCl}_{3}\right): \delta 10.16(\mathrm{~s}, 2 \mathrm{H}), 8.38(\mathrm{~d}, 2 \mathrm{H}), 8.24-$ $8.17(\mathrm{~m}, 2 \mathrm{H}), 8.08-8.00(\mathrm{~m}, 5 \mathrm{H})$, 7.97-7.93 (m, 2H).

2,6-bis(5-(6-(Oxazol-5-yl)pyridin-2-yl)oxazol-2-yl)pyridine 17 (iso-TOxaPy). A mixture of 22 (90 mg, $0.21 \mathrm{mmol})$, TosMIC (100 mg, $0.5 \mathrm{mmol})$, and $\mathrm{K}_{2} \mathrm{CO}_{3}(140 \mathrm{mg}, 1 \mathrm{mmol})$ in 15 $\mathrm{mL}$ of absolute ethanol was stirred at room temperature for 5 hours. The solvent was evaporated under reduced pressure and the crude product was purified by flash column chromatography $\left(\mathrm{SiO}_{2}\right)$, elution with $\mathrm{CH}_{2} \mathrm{Cl}_{2} / \mathrm{EtOH}$ (100/0 to 90/10), to afford desired compound 17 (iso-TOxaPy, $40 \mathrm{mg}, 37 \%$ ) (Pathway a).

\section{2-((2,6-bis(5-(6-(1,3-Dioxolan-2-yl)pyridin-2-yl)oxazol-2-yl)pyridin-4-yl)oxy)-N,N-}

dimethylethanamine 23. A mixture of compound 20 (1.36 g, $6.2 \mathrm{mmol})$, dibromopyridine derivative 14 (570 mg, $1.8 \mathrm{mmol})$, palladium acetate (180 mg, $0.8 \mathrm{mmol}), \mathrm{Cs}_{2} \mathrm{CO}_{3}(2.5 \mathrm{~g}, 7.7$ mmol), copper (I) iodide (700 mg, $3.7 \mathrm{mmol})$, and $\mathrm{PCy}_{3} \cdot \mathrm{HBF}_{4}(170 \mathrm{mg}, 0.5 \mathrm{mmol})$ was suspended in 1,4-dioxane (15 ml). The mixture was heated at reflux for 20 hours under argon. The solvent was evaporated under reduced pressure and the crude product was purified by flash column chromatography (neutral $\mathrm{Al}_{2} \mathrm{O}_{3}$ ), elution with EtOAc/EtOH (100/0 to 90/10), to afford product $23(660 \mathrm{mg}, 63 \%)$ as amorphous solid. ${ }^{1} \mathrm{H}$ NMR (300 $\left.\mathrm{MHz}, \mathrm{CDCl}_{3}\right)$ : $\delta$ 8.01$7.96(\mathrm{~m}, 4 \mathrm{H}), 7.91-7.85(\mathrm{~m}, 4 \mathrm{H}), 7.53(\mathrm{~d}, 2 \mathrm{H}), 5.91(\mathrm{~s}, 2 \mathrm{H}), 4.23(\mathrm{t}, 2 \mathrm{H}), 4.25-4.11(\mathrm{~m}, 8 \mathrm{H})$, $2.83(\mathrm{t}, 2 \mathrm{H}), 2.38(\mathrm{~s}, 6 \mathrm{H})$ 


\section{6,6'-(2,2'-(4-(2-(Dimethylamino)ethoxy)pyridine-2,6-diyl)bis(oxazole-5,2}

diyl))dipicolinalde hyde 24. A suspension of compound 23 (630 mg, $1 \mathrm{mmol})$ in $2 \mathrm{~N} \mathrm{HCl}$ (65 $\mathrm{mL}$ ) was stirred at room temperature for 4 days (until disappearance of signals belonging to dioxalane, monitored by NMR). The mixture was neutralized by addition of saturated $\mathrm{NaHCO}_{3}$ and the mixture was extracted thoroughly with $\mathrm{CH}_{2} \mathrm{Cl}_{2}$. The combined organic extracts were dried over $\mathrm{MgSO}_{4}$ and evaporated to dryness. The crude product 24 (470 mg, $87 \%$ ), obtained as a pale yellow solid, was used in the next step without further purification. M.p.> $150^{\circ} \mathrm{C} .{ }^{1} \mathrm{H} \mathrm{NMR}\left(300 \mathrm{MHz}, \mathrm{CDCl}_{3}\right): \delta 10.15$ (s, 2H), $8.20(\mathrm{~d}, 2 \mathrm{H}), 8.06-8.00(\mathrm{~m}, 4 \mathrm{H})$, 7.96-7.91 (m, 4H), $4.35(\mathrm{t}, 2 \mathrm{H}), 2.85(\mathrm{t}, 2 \mathrm{H}), 2.40(\mathrm{~s}, 6 \mathrm{H})$.

\section{2-((2,6-bis(5-(6-(Oxazol-5-yl)pyridin-2-yl)oxazol-2-yl)pyridin-4-yl)oxy)-N,N-}

dimethylethanamine 25 (iso-TOxaPy-1). A mixture of 24 (450 mg, $0.88 \mathrm{mmol}$ ), TosMIC (480 mg, $2.5 \mathrm{mmol})$, and $\mathrm{K}_{2} \mathrm{CO}_{3}(580 \mathrm{mg}, 4.2 \mathrm{mmol})$ in absolute ethanol (10 mL) was heated at reflux for 2 hours. The reaction mixture was evaporated to dryness, the residue partitioned between $\mathrm{CH}_{2} \mathrm{Cl}_{2}(120 \mathrm{~mL})$ and $\mathrm{H}_{2} \mathrm{O}(60 \mathrm{~mL})$ and the aqueous layer extracted thoroughly with $\mathrm{CH}_{2} \mathrm{Cl}_{2}$. The combined organic extracts were dried over $\mathrm{MgSO}_{4}$ and evaporated to dryness. The crude product was purified by flash column chromatography (neutral $\mathrm{Al}_{2} \mathrm{O}_{3}$ ), elution with $\mathrm{CH}_{2} \mathrm{Cl}_{2} / \mathrm{EtOH}$ (100/0 to 95/5), to afford desired product 25 (220 mg, 42\%) as orange solid. M.p. $>155{ }^{\circ} \mathrm{C} .{ }^{1} \mathrm{H}$ NMR $\left(300 \mathrm{MHz}, \mathrm{CDCl}_{3}\right): \delta 8.02$ (s, 2H), 7.99 (s, 2H), 7.97-7.96 (m, 4H), $7.91(\mathrm{~s}, 2 \mathrm{H}), 7.89(\mathrm{~s}, 2 \mathrm{H}), 7.69-7.66(\mathrm{~m}, 2 \mathrm{H}), 4.34(\mathrm{t}, 2 \mathrm{H}), 2.85(\mathrm{t}, 2 \mathrm{H}), 2.40(\mathrm{~s}, 6 \mathrm{H})$. Anal. Calcd for $\mathrm{C}_{31} \mathrm{H}_{24} \mathrm{~N}_{8} \mathrm{O}_{5} 2.7 \mathrm{H}_{2} \mathrm{O}$ : C, 58.44; H, 4.62; N, 17.59. Found: C, 58.54; H, 4.15; N, 17.21. HPLC injection: $T=4.98 \mathrm{~min}$. LRMS (ESI-MS): $\mathrm{m} / \mathrm{z}=589.3[\mathrm{M}+\mathrm{H}]^{+}$. HRMS (ESIMS): 589.1480 (calculated: $589.1485 \mathrm{C}_{31} \mathrm{H}_{25} \mathrm{~N}_{8} \mathrm{O}_{5}{ }^{+}$).

Formation of mesylate salt (iso-TOxaPy-2). To the free base 25 (24 mg) dissolved in NMP $(0.7 \mathrm{~mL})$ were added $11 \mu \mathrm{L}$ of $\mathrm{CH}_{3} \mathrm{SO}_{3} \mathrm{H}$ dissolved in NMP. After heating at $60^{\circ} \mathrm{C}$, the mixture was left 1 hour at room temperature and ethyl ether $(2.5 \mathrm{~mL})$ was added. The 
precipitate was collected by filtration, washed twice with a small amount of ethyl ether and the resulting hygroscopic mesylate salt was dried under vacuum (26 mg). Anal. Calcd for $\mathrm{C}_{31} \mathrm{H}_{24} \mathrm{~N}_{8} \mathrm{O}_{5} \cdot \mathrm{CH}_{3} \mathrm{SO}_{3} \mathrm{H} 3 \mathrm{H}_{2} \mathrm{O}: \mathrm{C}, 52.03 ; \mathrm{H}, 4.60 ; \mathrm{N}, 15.17$. Found: C, 51.74; H, 5.01; N, 15.17. HPLC injection: $T=5.01 \mathrm{~min}$. LRMS (ESI-MS): $\mathrm{m} / \mathrm{z}=589.3[\mathrm{M}+\mathrm{H}]^{+}$.

Formation of maleate salt (iso-TOxaPy-3). To the free base $25(100 \mathrm{mg})$ dissolved in acetone and THF (30 and $7 \mathrm{~mL})$ was added maleic acid $(50 \mathrm{mg})$ in acetone $(5 \mathrm{~mL})$. After heating at $50^{\circ} \mathrm{C}$, the mixture was left for 3 hours at room temperature, the solvent removed under reduced pressure, and acetone $(5 \mathrm{~mL})$ was added. The precipitate was collected by filtration and washed with acetone $(2 \times 2 \mathrm{~mL})$. The resulting hygroscopic maleate salt was dried under vacuum $(90 \mathrm{mg})$. Anal. Calcd for $\mathrm{C}_{31} \mathrm{H}_{24} \mathrm{~N}_{8} \mathrm{O}_{5} \cdot \mathrm{C}_{4} \mathrm{H}_{4} \mathrm{O}_{4} \cdot 2.2 \mathrm{H}_{2} \mathrm{O}: \mathrm{C}, 56.48 ; \mathrm{H}, 4.36$; N, 15.06. Found: C, 56.10; H, 4.08; N, 14.61. HPLC injection: $T=4.98$ min. LRMS (ESIMS): $\mathrm{m} / \mathrm{z}=589.3[\mathrm{M}+\mathrm{H}]^{+}$.

Synthesis of 6,6'-bis(5-(6-(Oxazol-5-yl)pyridin-2-yl)oxazol-2-yl)-2,2'-bipyridine 29 (isoTOxabiPy).

6,6'-bis(5-(6-(1,3-Dioxolan-2-yl)pyridin-2-yl)oxazol-2-yl)-2,2'-bipyridine 27. A mixture of 20 (1.27 g, 4.9 mmol), 6,6'-dibromo-2,2'-bipyridine 26 (490 mg, $1.6 \mathrm{mmol}$ ), palladium acetate (220 mg, $1 \mathrm{mmol}), \mathrm{Cs}_{2} \mathrm{CO}_{3}(2.6 \mathrm{~g}, 8 \mathrm{mmol})$, copper (I) iodide (850 mg, $\left.4.5 \mathrm{mmol}\right)$, and $\mathrm{PCy}_{3} \cdot \mathrm{HBF}_{4}(180 \mathrm{mg}, 0.5 \mathrm{mmol})$ was suspended in 1,4-dioxane $(12 \mathrm{ml})$. The mixture was heated at reflux for 18 hours under argon. The solvent was evaporated under reduced pressure and the crude product was purified by flash column chromatography (neutral $\mathrm{Al}_{2} \mathrm{O}_{3}$ ), elution with $\mathrm{CH}_{2} \mathrm{Cl}_{2} / \mathrm{EtOAC}$ (100/0 to 60/40), to afford product $27(650 \mathrm{mg}, 71 \%$ ) as fair beige powder. M.p. $>260{ }^{\circ} \mathrm{C} .{ }^{1} \mathrm{H}$ NMR $\left(300 \mathrm{MHz}, \mathrm{CDCl}_{3}\right): \delta 8.82(\mathrm{~d}, 2 \mathrm{H}), 8.28(\mathrm{~d}, 2 \mathrm{H}), 8.10-8.02$ (m, 2H), $7.99(\mathrm{~s}, 2 \mathrm{H}), 7.94-7.85(\mathrm{~m}, 4 \mathrm{H}), 7.57-7.52(\mathrm{~m}, 2 \mathrm{H}), 5.92(\mathrm{~s}, 2 \mathrm{H}), 4.26-4.12(\mathrm{~m}, 8 \mathrm{H})$. 
6,6'-bis(5-(6-(oxazol-5-yl)pyridin-2-yl)oxazol-2-yl)-2,2'-bipyridine 29 (iso-TOxabiPy). 6,6'-(2,2'-([2,2'-Bipyridine]-6,6'-diyl)bis(oxazole-5,2-diyl))dipicolinaldehyde $\quad 28 . \quad$ A suspension of compound $27(620 \mathrm{mg}, 1 \mathrm{mmol})$ in $2 \mathrm{~N} \mathrm{HCl}(65 \mathrm{~mL})$ was heated at $100^{\circ} \mathrm{C}$ for 4 hours (until disappearance of signals belonging to dioxalane, monitored by NMR). Water was added $(100 \mathrm{~mL})$ and the mixture was neutralized by addition of saturated $\mathrm{NaHCO}_{3}$. The mixture was stirred at room temperature overnight. The precipitate was collected by filtration, washed with water, dried (at $\left.100^{\circ} \mathrm{C}\right)$ and the crude product $28(550 \mathrm{mg})$ was used without further purification for the next step. A mixture of crude $\mathbf{2 8}(550 \mathrm{mg})$, TosMIC (720 mg, 3.7 mmol), and $\mathrm{K}_{2} \mathrm{CO}_{3}(660 \mathrm{mg}, 4.8 \mathrm{mmol})$ in absolute ethanol $(40 \mathrm{~mL})$ was heated at reflux for 2.5 hours. The reaction mixture was evaporated to dryness, the residue partitioned between $\mathrm{CH}_{2} \mathrm{Cl}_{2}(250 \mathrm{~mL})$ and $\mathrm{H}_{2} \mathrm{O}(150 \mathrm{~mL})$ and the aqueous layer was extracted thoroughly with $\mathrm{CH}_{2} \mathrm{Cl}_{2}$. The combined organic extracts were dried over $\mathrm{MgSO}_{4}$ and evaporated to dryness. The crude product was purified by flash column chromatography $\left(\mathrm{SiO}_{2}\right)$, elution with $\mathrm{CH}_{2} \mathrm{Cl}_{2} / \mathrm{EtOH}$ (100/0 to 50/50). The resulting crude product was suspended in ethanol (6 mL) and stirred at room temperature for 2 hours. The precipitate was collected by filtration, washed with small amount of ethanol $(2 \times 1 \mathrm{~mL})$, and dried in the air to afford desired product 29 (110 mg, $18 \%$ two steps overall yield) as a beige powder. M.p. > $155{ }^{\circ} \mathrm{C} .{ }^{1} \mathrm{H}$ NMR $(300$ MHz, DMSO-d $\left.\mathrm{d}_{6}\right): \delta 8.77(\mathrm{~d}, 2 \mathrm{H}), 8.64(\mathrm{~s}, 2 \mathrm{H}), 8.39-8.29(\mathrm{~m}, 4 \mathrm{H}), 8.17-8.12(\mathrm{~m}, 4 \mathrm{H}), 8.00-$ $7.98(\mathrm{~m}, 4 \mathrm{H}), 7.84(\mathrm{~d}, 2 \mathrm{H}), 7.48(\mathrm{~d}, 1 \mathrm{H}), 7.12(\mathrm{~d}, 1 \mathrm{H})$. HPLC injection: $T=7.02 \mathrm{~min}$. LRMS (ESI-MS): m/z= $579.3[\mathrm{M}+\mathrm{H}]^{+}$. HRMS (ESI-MS): 601.1355 (calculated: 601.1349 $\mathrm{C}_{32} \mathrm{H}_{18} \mathrm{~N}_{8} \mathrm{O}_{4} \mathrm{Na}^{+}$.

4.2 FRET-Melting experiments. Stabilization of compounds with quadruplex-structures was monitored via FRET-melting assay performed in 96-well plates on real time PCR apparatus as follows: equilibration $5 \mathrm{~min}$ at $25^{\circ} \mathrm{C}$ and then increase $0.5^{\circ} \mathrm{C}$ every minute until $95^{\circ} \mathrm{C}$. Each experimental condition was tested in duplicated in a volume of $25 \mu \mathrm{L}$ for each sample. FRET- 
melting assay was performed with oligonucleotides that mimic the human telomeric sequence and the C-myc proto-oncogene sequence (table 4) equipped with FRET partners at each extremity, and the control duplex ds 26 . The oligonucleotides were prepared at $0.2 \mu \mathrm{M}$, the ligands at $1 \mu \mathrm{M}$ and competitors at 3 and $10 \mu \mathrm{M}$ final concentration. Measurements were made with excitation at $492 \mathrm{~nm}$ and detection at $516 \mathrm{~nm}$ in a buffer of lithium cacodylated (10 $\mathrm{mM}, \mathrm{pH} 7.2), \mathrm{NaCl}(100 \mathrm{mM})$ or $\mathrm{KCl}(10 \mathrm{mM}$, completed by $90 \mathrm{mM} \mathrm{LiCl}$ for F21T, and 1 $\mathrm{mM}$, completed by $99 \mathrm{mM} \mathrm{LiCl}$ for C-myc) then heated at $90^{\circ} \mathrm{C}$ for $5 \mathrm{~min}$ and left to cool down at $4{ }^{\circ} \mathrm{C}$ overnight. Oligonucleotide melting was monitored by observing 6carboxyfluorescein (6-FAM) emission, which was normalized between 0 and 1 . The melting temperature $\left(\mathrm{T}_{\mathrm{m}}\right)$ was defined as the temperature at the inflection point of the sigmoid doseresponse best fitting curve.

Table 4. Oligonucleotide Sequences (5'-3')

F21T [6FAM-GGGTTAGGGTTAGGGTTAGGG-3TAMRA]

FMycT

[6FAMTTGAGGGTGGGTAGGGTGGGTAA-3TAMRA]

ds26

CAATCGGATCGAATTCGATCCGATTG

4.3 Fluorescence titrations. Fluorescence titrations were performed in lithium cacodylate buffer solution $(10 \mathrm{mM})$ containing $\mathrm{KCl}(100 \mathrm{mM})$ and adjusted to $\mathrm{pH}$ 7.2. The fluorescence spectra were recorded with a Cary Eclipse Fluorescence spectrophotometer (Agilent Technologies), in a 1-mL quartz cell (path length: $1 \mathrm{~cm}$ ) using the following experimental parameters; optical slit widths, 5.0/5.0 nm; speed, slow; and Intensity, high. Fluorescence titrations were carried out in the subsequent way. Fluorescence spectra of iso-TOxaPy, isoTOxabiPy, and iso-TOxaPy-1 alone $\left(0.5 \mu \mathrm{M} ; \mathrm{F}_{0}\right)$ and upon addition of increasing amounts of quadruplex DNA (22AG and c-Myc, Table 5) $(\mathrm{F})$ were recorded $\left(\lambda_{\text {exc }}: 330 \mathrm{~nm}\right.$ for iso- 
TOxaPy, iso-TOxabiPy and $340 \mathrm{~nm}$ for iso-TOxaPy-1). The fluorescence enhancement (350$650 \mathrm{~nm}$ or $340-650 \mathrm{~nm})$ was plotted as a function of the concentration $(\mu \mathrm{M})$ of added G4DNA.

Table 5. Oligonucleotide Sequences (5'-3')

$22 \mathrm{AG}$

$\mathrm{AG}_{3} \mathrm{TTAG}_{3} \mathrm{TTAG}_{3} \mathrm{TTAG}_{3}$

c-Myc

$\mathrm{TGAG}_{3} \mathrm{TG}_{3} \mathrm{TAG}_{3} \mathrm{TG}_{3} \mathrm{TAA}$

4.4 Cell lines and cell cycle analysis. Cell lines obtained from ATCC were cultured under suggested conditions. HeLa cells were synchronized by serum deprivation for $96 \mathrm{~h}$. After release, they were treated with the compounds $(1 \mu \mathrm{M})$ for 48 hours and compared to control cells. For determination of cell cycle profiles, cells were fixed with ice-cold $70 \%$ ethanol for 1 hour, and then, incubated with propidium iodide solution $(50 \mu \mathrm{g} / \mathrm{ml})$ in the presence of 0.2 $\mathrm{mg} / \mathrm{ml} \mathrm{RNase}$ A for 15 minutes at $37^{\circ} \mathrm{C}$. DNA content was measured using the BD Accuri C6 flow cytometer (BD Biosciences, US) and CFlow Plus software. ${ }^{49}$

4.5 Cell viability. Cell proliferation assays were conducted in 96-well culture plates. Cells, at the appropriate density, were seeded at day 0 and serial dilutions of compound were added at day 1. Assays were run in triplicate and the viable cell number was determined $72 \mathrm{~h}$ post addition of the drug, by the MTS (Promega). A first trial was conducted on all the available compounds and then, two additional experiments were run on compounds of interest.

4.6 Kinase profiling and ATP competition assays. The assays were performed at the International Centre for kinase profiling in Dundee (UK). Assays are done in duplicate with recombinant kinases and known kinase inhibitors are challenged in parallel. Protein kinase assays used radioactive filter and 33P-ATP, and lipid kinases are screened with the ADP-Glo 
assays (Promega). Controls were done in the absence of compound, assays are validated by quantifying the Z' value on each plate, that must be higher than 6. ATP competition assays were run under the same quality controls. Rock-2 kinase activity was monitored in the presence of iso-TOxaPy at five ATP concentrations: at the $\mathrm{km}(20 \mu \mathrm{M})$, two above the $\mathrm{Km}$ and two below it.

4.7 Immunoblotting. Cells were extracted by RIPA-buffer supplemented with protease and phosphatase inhibitors. The western blott was performed as described. ${ }^{53}$ The membrane was split in two and incubated with an actin antibody (Cell Signaling, 1/1000) or an anti-phosphoCofilin-Ser3 (Cell Signaling, 1/1000). Signals were revealed by luminescence and collected by the chemidoc (BioRad).

4.8 Immunofluorescence. HeLa cells grown on glass coverslips were treated with the compounds $(1 \mu \mathrm{M})$ or DMSO (control, Co) and then, fixed with formaldehyde $4 \%$ for 10 minutes at $37^{\circ} \mathrm{C}$. Immunofluorescences were performed as previously described. ${ }^{54}$ Coverslips were incubated with the antibodies directed against the following antigens: phospho-histone H2A-X (Upstate, 1/2000); alpha-tubulin (Sigma 1/1000); phospho-tyrosine (Cell Signaling, 1/100); phospho-MYPT1-Thr853 (Elabscience, 1/100); phospho-cofilin-Ser3 (Cell Signaling, 1/100). Actin was stained by either phalloidin-rhodamin $(1 \mu \mathrm{g} / \mathrm{ml})$ or phalloidin-Atto 488 . DNA was visualized with Hoechst 33342 (Sigma, $0.5 \mu \mathrm{g} / \mathrm{ml}$ ). Images were collected with a ZEISS 710 Laser Scanning Confocal microscope with a $63 \times$-immersion oil objective. Slices of $0.5 \mu \mathrm{m}$ are shown. The medium filter $(3,3,0)$ from the Zen-software was applied to all images. Alternatively, the whole fluorescence was imaged by z-stacking and the signal presented as a projection (zp) generated by the Zeis-zen software.

4.9 Time lapse. Ex vivo experiments were conducted on cells grown on Lab-Tek chambered coverglass (Nalgen Nunc International) and maintained under standard culture conditions 
$\left(37^{\circ} \mathrm{C}, 5 \% \mathrm{CO}_{2}\right)$. Images were acquired on a Zeiss dynascope confocal microscope using a PlanApochromat $40 \times$ water immersion objective. ${ }^{49}$ Images were analysed with the Zen software provided by Zeiss. Compounds were added around $15 \mathrm{~h}$ before imaging. At least 15 fields were imaged for each tested compound and three independent experiments were conducted.

4.10 Multicellular tumour spheroid (MTS) models. Spheroids were generated by plating HeLa cells, at 800 cells/well, into ultra-low adherence 96-well plates (Corning, Tewksbury, USA). ${ }^{55}$ These plates stimulate spontaneous formation of a single spheroid of cells within 24 hours of incubation at $37^{\circ} \mathrm{C}, 5 \% \mathrm{CO}_{2}$. Spheroids grew in complete medium as in $2 \mathrm{D}$-cultures in the final volume of $200 \mu \mathrm{L}$. Spheroids were imaged in live conditions directly in the 96well plate. For measuring their expansion, spheroids were imaged with a Zeiss 510-confocal microscope, each day, with a 10-X objective and then the area of the larger section was determined, for each spheroid, by Image $\mathrm{J}$ software. Experiments were repeated on 5 spheroids. ${ }^{49}$ Finally, at the end-point, the number of living cells was determined by the celltiter Glo-3D kit under conditions suggested by the manufacturer (Promega). Drug treatments were performed at day 3 . Three different concentrations were used.

\section{Abbreviations used}

Rock-2, Rho-associated protein kinase 2; G4, G-quadruplex; mRNA, messenger RNA; SCNAs, somatic copy number alterations; SCN, somatic copy number; SAR, structure activity relationship; GTPase, guanosine triphosphate phosphohydrolase; TosMIC, ptoluenesulfonylmethyl isocyanide; $\mathrm{PCy}_{3} \cdot \mathrm{HBF}_{4}$, tricyclohexylphosphine tetrafluoroborate; THF, tetrahydrofuran; pTsOH, p-toluenesulfonic acid; FRET, Forster resonance energy transfer; $\mathrm{IC}_{50}$, half maximal inhibitory concentration; FACS, Fluorescence Activated Cell Sorter; $\gamma \mathrm{H} 2 \mathrm{AX}$, phosphorylated histone subtype H2A isoform X; PI3K, phosphoinositide 3- 
kinase; DMPK, dystrophia myotonica protein kinase; ATP, adenosine triphosphate; DMSO, dimethyl sulfoxide; ESI-MS, electrospray ionization mass spectrometry; FA, formic acid; $\mathrm{MeCN}$, acetonitrile; PCR, polymerase chain reaction; $n \mathrm{BuOH}$, normal butanol; NMP, Nmethyl-2-pyrrolidone.

\section{Supporting Information.}

Spectral data: ${ }^{1} \mathrm{H}$ NMR, for all final compounds, HRMS, and HPLC-MS for iso-TOxaPy, isoTOxaPy-1, and iso-TOxabiPy. Biophysical data: FRET melting competition assay human telomeric and c-Myc oncogene sequence, and fluorescence titration in the presence of isoTOxaPy, iso-TOxaPy-1, and iso-TOxabiPy with the human telomeric and c-Myc oncogene sequences. Effects of iso-TOxaPy, iso-TOxaPy-1 and iso-ToxabiPy on cells. Kinase profiling and ATP competition assays as well as the list of challenge kinases. Molecular formula strings (CSV).

\section{Ancillary information}

\section{AUTHOR INFORMATION}

\section{Corresponding Authors}

*M-P. T-F. : email, mp.teulade-fichou@curie.fr

* A. M.: email, annie.molla@univ-grenoble-alpes.fr

\section{ORCID}

Annie Molla: (0000-0002-9859-8682)

Marie-Paule Teulade-Fichou: (0000-0002-2053-7513)

\section{Funding Sources}


This work was supported by CNRS, Inserm, University Grenoble Alpes and Institut Curie.

\section{Conflict of interest}

The authors declare no competing financial interest.

\section{REFERENCES}

1. Wang, Y.; Patel, D. J., Solution structure of a parallel-stranded G-quadruplex DNA. $J$ Mol Biol 1993, 234 (4), 1171-1183.

2. Bochman, M. L.; Paeschke, K.; Zakian, V. A., DNA secondary structures: stability and function of G-quadruplex structures. Nat Rev Genet 2012, 13 (11), 770-780.

3. Hansel-Hertsch, R.; Di Antonio, M.; Balasubramanian, S., DNA G-quadruplexes in the human genome: detection, functions and therapeutic potential. Nat Rev Mol Cell Biol 2017, $18(5), 279-284$.

4. Chambers, V. S.; Marsico, G.; Boutell, J. M.; Di Antonio, M.; Smith, G. P.; Balasubramanian, S., High-throughput sequencing of DNA G-quadruplex structures in the human genome. Nat Biotechnol 2015, 33 (8), 877-881.

5. Harkness, R. W. t.; Mittermaier, A. K., G-quadruplex dynamics. Biochim Biophys Acta 2017, 1865 (11 Pt B), 1544-1554.

6. Gray, L. T.; Vallur, A. C.; Eddy, J.; Maizels, N., G quadruplexes are genomewide targets of transcriptional helicases XPB and XPD. Nat Chem Biol 2014, 10 (4), 313-318.

7. Paeschke, K.; Bochman, M. L.; Garcia, P. D.; Cejka, P.; Friedman, K. L.; Kowalczykowski, S. C.; Zakian, V. A., Pif1 family helicases suppress genome instability at G-quadruplex motifs. Nature 2013, 497 (7450), 458-462.

8. Maizels, N., G4-associated human diseases. EMBO Rep 2015, 16 (8), 910-922. 
9. Ohnmacht, S. A.; Marchetti, C.; Gunaratnam, M.; Besser, R. J.; Haider, S. M.; Di Vita, G.; Lowe, H. L.; Mellinas-Gomez, M.; Diocou, S.; Robson, M.; Sponer, J.; Islam, B.; Pedley, R. B.; Hartley, J. A.; Neidle, S., A G-quadruplex-binding compound showing antitumour activity in an in vivo model for pancreatic cancer. Sci Rep 2015, 5, 11385.

10. Lavrado, J.; Brito, H.; Borralho, P. M.; Ohnmacht, S. A.; Kim, N. S.; Leitao, C.; Pisco, S.; Gunaratnam, M.; Rodrigues, C. M.; Moreira, R.; Neidle, S.; Paulo, A., KRAS oncogene repression in colon cancer cell lines by G-quadruplex binding indolo[3,2-c]quinolines. Sci Rep 2015, 5, 9696.

11. Neidle, S., Quadruplex nucleic acids as targets for anticancer therapeutics. Nature Reviews Chemistry 2017, 1 (5).

12. Muller, S.; Rodriguez, R., G-quadruplex interacting small molecules and drugs: from bench toward bedside. Expert Rev Clin Pharmacol 2014, 7 (5), 663-679.

13. Granotier, C.; Pennarun, G.; Riou, L.; Hoffschir, F.; Gauthier, L. R.; De Cian, A.; Gomez, D.; Mandine, E.; Riou, J. F.; Mergny, J. L.; Mailliet, P.; Dutrillaux, B.; Boussin, F. D., Preferential binding of a G-quadruplex ligand to human chromosome ends. Nucleic Acids Res 2005, 33 (13), 4182-4190.

14. Pennarun, G.; Granotier, C.; Hoffschir, F.; Mandine, E.; Biard, D.; Gauthier, L. R.; Boussin, F. D., Role of ATM in the telomere response to the G-quadruplex ligand 360A. Nucleic Acids Res 2008, 36 (5), 1741-1754.

15. Biffi, G.; Tannahill, D.; Balasubramanian, S., An intramolecular G-quadruplex structure is required for binding of telomeric repeat-containing RNA to the telomeric protein TRF2. J Am Chem Soc 2012, 134 (29), 11974-11976. 
16. Zimmer, J.; Tacconi, E. M. C.; Folio, C.; Badie, S.; Porru, M.; Klare, K.; Tumiati, M.; Markkanen, E.; Halder, S.; Ryan, A.; Jackson, S. P.; Ramadan, K.; Kuznetsov, S. G.; Biroccio, A.; Sale, J. E.; Tarsounas, M., Targeting BRCA1 and BRCA2 deficiencies with Gquadruplex-interacting compounds. Mol Cell 2016, 61 (3), 449-460.

17. Merle, P.; Gueugneau, M.; Teulade-Fichou, M. P.; Muller-Barthelemy, M.; Amiard, S.; Chautard, E.; Guetta, C.; Dedieu, V.; Communal, Y.; Mergny, J. L.; Gallego, M.; White, C.; Verrelle, P.; Tchirkov, A., Highly efficient radiosensitization of human glioblastoma and lung cancer cells by a G-quadruplex DNA binding compound. Sci Rep 2015, 5, 16255.

18. Balasubramanian, S.; Hurley, L. H.; Neidle, S., Targeting G-quadruplexes in gene promoters: a novel anticancer strategy? Nat Rev Drug Discov 2011, 10 (4), 261-275.

19. Boddupally, P. V.; Hahn, S.; Beman, C.; De, B.; Brooks, T. A.; Gokhale, V.; Hurley, L. H., Anticancer activity and cellular repression of c-MYC by the G-quadruplex-stabilizing 11-piperazinylquindoline is not dependent on direct targeting of the G-quadruplex in the cMYC promoter. J Med Chem 2012, 55 (13), 6076-6086.

20. Felsenstein, K. M.; Saunders, L. B.; Simmons, J. K.; Leon, E.; Calabrese, D. R.; Zhang, S.; Michalowski, A.; Gareiss, P.; Mock, B. A.; Schneekloth, J. S., Jr., Small molecule microarrays enable the identification of a selective, quadruplex-binding inhibitor of MYC expression. ACS Chem Biol 2016, 11 (1), 139-148.

21. Dutta, D.; Debnath, M.; Muller, D.; Paul, R.; Das, T.; Bessi, I.; Schwalbe, H.; Dash, J., Cell penetrating thiazole peptides inhibit c-MYC expression via site-specific targeting of cMYC G-quadruplex. Nucleic Acids Res 2018, 46 (11), 5355-5365. 
22. Panda, D.; Saha, P.; Das, T.; Dash, J., Target guided synthesis using DNA nanotemplates for selectively assembling a G-quadruplex binding c-MYC inhibitor. Nat Commun 2017, 8, 16103.

23. Salvati, E.; Botta, L.; Amato, J.; Di Leva, F. S.; Zizza, P.; Gioiello, A.; Pagano, B.; Graziani, G.; Tarsounas, M.; Randazzo, A.; Novellino, E.; Biroccio, A.; Cosconati, S., Lead discovery of dual G-quadruplex stabilizers and poly(ADP-ribose) polymerases (PARPs) inhibitors: a new avenue in anticancer treatment. $J$ Med Chem 2017, 60 (9), 3626-3635.

24. Hamon, F.; Largy, E.; Guedin-Beaurepaire, A.; Rouchon-Dagois, M.; Sidibe, A.; Monchaud, D.; Mergny, J. L.; Riou, J. F.; Nguyen, C. H.; Teulade-Fichou, M. P., An acyclic oligoheteroaryle that discriminates strongly between diverse G-quadruplex topologies. Angew Chem Int Ed Engl 2011, 50 (37), 8745-8749.

25. Nguyen, C.-H.; Rouchon Dagois, M.; Guedin-Beaurepaire, A.; Monchaud, D.; Teulade-Fichou, M.-P.; Riou, J.-F.; Mergny, J.-L.; Grierson, D. Preparation of Polyheteroaryl Derivatives for the Treatment of Cancer and Infectious Diseases and as Quadruplex-specific DNA Probes. WO2010049915 (A1), May 6, 2010.

26. Ohnmacht, S. A.; Ciancimino, C.; Vignaroli, G.; Gunaratnam, M.; Neidle, S., Optimization of anti-proliferative activity using a screening approach with a series of bisheterocyclic G-quadruplex ligands. Bioorg Med Chem Lett 2013, 23 (19), 5351-5355.

27. Dumat, B.; Faurel-Paul, E.; Fornarelli, P.; Saettel, N.; Metge, G.; Fiorini-Debuisschert, C.; Charra, F.; Mahuteau-Betzer, F.; Teulade-Fichou, M. P., Influence of the oxazole ring connection on the fluorescence of oxazoyl-triphenylamine biphotonic DNA probes. Org Biomol Chem 2016, 14 (1), 358-370. 
28. Bostrom, J.; Hogner, A.; Llinas, A.; Wellner, E.; Plowright, A. T., Oxadiazoles in medicinal chemistry. $J$ Med Chem 2012, 55 (5), 1817-1830.

29. Petenzi, M.; Verga, D.; Largy, E.; Hamon, F.; Doria, F.; Teulade-Fichou, M. P.; Guedin, A.; Mergny, J. L.; Mella, M.; Freccero, M., Cationic pentaheteroaryls as selective Gquadruplex ligands by solvent-free microwave-assisted synthesis. Chemistry 2012, 18 (45), 14487-14496.

30. Julian, L.; Olson, M. F., Rho-associated coiled-coil containing kinases (ROCK): structure, regulation, and functions. Small GTPases 2014, 5, e29846.

31. Amano, M.; Chihara, K.; Kimura, K.; Fukata, Y.; Nakamura, N.; Matsuura, Y.; Kaibuchi, K., Formation of actin stress fibers and focal adhesions enhanced by Rho-kinase. Science 1997, 275 (5304), 1308-1311.

32. Yoneda, A.; Multhaupt, H. A.; Couchman, J. R., The Rho kinases I and II regulate different aspects of myosin II activity. J Cell Biol 2005, 170 (3), 443-453.

33. Shah, S.; Savjani, J., A review on ROCK-II inhibitors: From molecular modelling to synthesis. Bioorg Med Chem Lett 2016, 26 (10), 2383-2391.

34. Olson, M. F., Applications for ROCK kinase inhibition. Curr Opin Cell Biol 2008, 20 (2), 242-248.

35. Rath, N.; Olson, M. F., Rho-associated kinases in tumorigenesis: re-considering ROCK inhibition for cancer therapy. EMBO Rep 2012, 13 (10), 900-908.

36. Hoarau, C. d. K., A. D. F. Bracq, N. Grandclaudon, P. Couture, A. Marsais, F., Regioselective palladium-catalyzed phenylation of ethyl 4-oxazolecarboxylate. Tetrahedron Letters 2005, 46 (49), 8573-8577. 
37. Hardouin, C.; Kelso, M. J.; Romero, F. A.; Rayl, T. J.; Leung, D.; Hwang, I.; Cravatt, B. F.; Boger, D. L., Structure-activity relationships of alpha-ketooxazole inhibitors of fatty acid amide hydrolase. J Med Chem 2007, 50 (14), 3359-3368.

38. Rodriguez-Ubis, J. C. S., R. Barroso G. Juanes O, Brunet E., Lanthanide Complexes of Polyacid Ligands derived from 2, 6-bis(pyrazol-1-yl)pyridine, pyrazine, and 6, 6'bis(pyrazol-1-yl)-2, 2'-bipyridine: Synthesis and luminescence properties. Helvetica Chimica Acta 1997, 80 (1), 86-96.

39. Balboula, A. Z.; Stein, P.; Schultz, R. M.; Schindler, K., Knockdown of RBBP7 unveils a requirement of histone deacetylation for CPC function in mouse oocytes. Cell Cycle 2014, 13 (4), 600-611.

40. Vacher, B. B., B.; Funes, P.; Jubault, N.; Koek, W.; Assie, M.; Cosi, C., Design and synthesis of a series of 6-substituted-2-pyridinylmethylamine derivatives as novel, highaffinity, selective agonists at 5-HT1A receptors. J. Med. Chem. 1998, 25 (41), 5070.

41. Linder, J.; Garner, T. P.; Williams, H. E.; Searle, M. S.; Moody, C. J., Telomestatin: formal total synthesis and cation-mediated interaction of its seco-derivatives with Gquadruplexes. J Am Chem Soc 2011, 133 (4), 1044-1051.

42. Minata, M.; Gu, C.; Joshi, K.; Nakano-Okuno, M.; Hong, C.; Nguyen, C. H.; Kornblum, H. I.; Molla, A.; Nakano, I., Multi-kinase inhibitor C1 triggers mitotic catastrophe of glioma stem cells mainly through MELK kinase inhibition. PLoS One 2014, 9 (4), e92546.

43. Dall'Armi, C.; Devereaux, K. A.; Di Paolo, G., The role of lipids in the control of autophagy. Curr Biol 2013, 23 (1), R33-45.

44. Mueller, B. K.; Mack, H.; Teusch, N., Rho kinase, a promising drug target for neurological disorders. Nat Rev Drug Discov 2005, 4 (5), 387-398. 
45. Feng, Y.; LoGrasso, P. V.; Defert, O.; Li, R., Rho kinase (ROCK) Inhibitors and their therapeutic potential. $J$ Med Chem 2016, 59 (6), 2269-300.

46. Burridge, K.; Turner, C. E.; Romer, L. H., Tyrosine phosphorylation of paxillin and pp125FAK accompanies cell adhesion to extracellular matrix: a role in cytoskeletal assembly. J Cell Biol 1992, 119 (4), 893-903.

47. Shibata, K.; Sakai, H.; Huang, Q.; Kamata, H.; Chiba, Y.; Misawa, M.; Ikebe, R.; Ikebe, M., Rac1 regulates myosin II phosphorylation through regulation of myosin light chain phosphatase. J Cell Physiol 2015, 230 (6), 1352-1364.

48. Lee, S.; Helfman, D. M., Cytoplasmic p21Cip1 is involved in ras-induced inhibition of the ROCK/LIMK/cofilin pathway. J Biol Chem 2004, 279 (3), 1885-1891.

49. Le, L. T.; Couvet, M.; Favier, B.; Coll, J. L.; Nguyen, C. H.; Molla, A., Discovery of benzo[e]pyridoindolones as kinase inhibitors that disrupt mitosis exit while erasing AMPKThr172 phosphorylation on the spindle. Oncotarget 2015, 6 (26), 22152-22166.

50. Khamar, B. M.; Modi, I. A.; Venkatraman, J.; Ponnaiah, R.; Nori, D. S.; Gajula, M. R.; Renugadevi, G.; Shashikala, K. N.; Rudramuni, S. M. A Process for Producing Itopride via a Novel Intermediate N-(4-hydroxybenzyl)-3,4-dimethoxybenzamide. WO2007074386 (A2), July 5, 2007.

51. Hickmott, P. W. S. W., W.; Murray-Rust P., Introduction of pharmacophoric groups into polycyclic systems. Part 3. Amine derivatives of adamantane and diaza-adamantane. $J$. Chem. Soc., Perkin Trans. 1985, 1 (1), 2039-2044

52. Vacher, B.; Bonnaud, B.; Funes, P.; Jubault, N.; Koek, W.; Assie, M. B.; Cosi, C., Design and synthesis of a series of 6-substituted-2-pyridinylmethylamine derivatives as novel, high-affinity, selective agonists at 5-HT1A receptors. $J$ Med Chem 1998, 41 (25), 5070-5083. 
53. Le, L. T.; Vu, H. L.; Naud-Martin, D.; Bombled, M.; Nguyen, C. H.; Molla, A., Hydrosoluble benzo[e]pyridoindolones as potent inhibitors of aurora kinases. ChemMedChem 2013, 8 (2), 289-296.

54. Le, L. T.; Vu, H. L.; Nguyen, C. H.; Molla, A., Basal aurora kinase B activity is sufficient for histone H3 phosphorylation in prophase. Biol Open 2013, 2 (4), 379-386.

55. Molla, A.; Couvet, M.; Coll, J. L., Unsuccessful mitosis in multicellular tumour spheroids. Oncotarget 2017, 8 (17), 28769-28784. 